\title{
The Use of Digital and Remote Communication Technologies as a Tool for Multiple Sclerosis Management: Narrative Review
}

Martin Marziniak $^{1}$, MD, PhD; Giampaolo Brichetto ${ }^{2}, \mathrm{MD}, \mathrm{PhD}$; Peter Feys ${ }^{3}$, PhD; Uta Meyding-Lamadé ${ }^{4}, \mathrm{MD}, \mathrm{PhD}$; Karen Vernon ${ }^{5}$, RGN, PGDip; Sven G Meuth ${ }^{6}, \mathrm{MD}, \mathrm{PhD}$

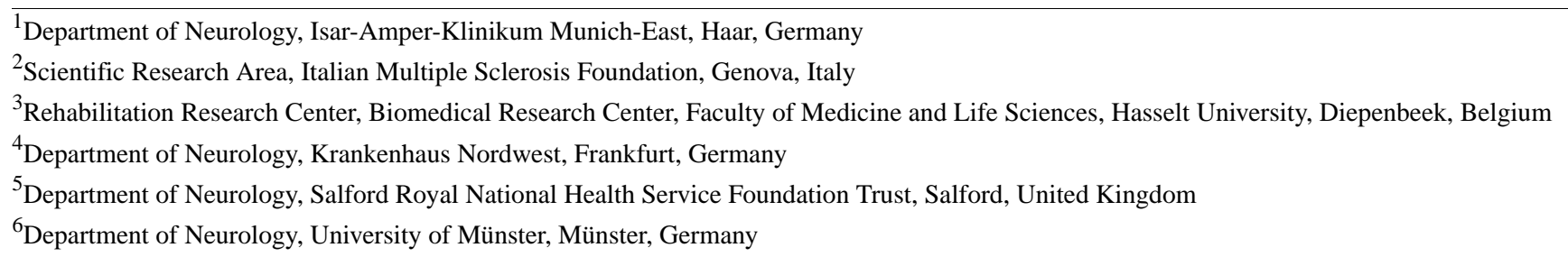

Corresponding Author:

Sven G Meuth, MD, PhD

Department of Neurology

University of Münster

Schlossplatz 2

Münster, 48149

Germany

Phone: 4902518344463

Email: $\underline{\text { sven.meuth@ukmuenster.de }}$

\begin{abstract}
Despite recent advances in multiple sclerosis (MS) care, many patients only infrequently access health care services, or are unable to access them easily, for reasons such as mobility restrictions, travel costs, consultation and treatment time constraints, and a lack of locally available MS expert services. Advances in mobile communications have led to the introduction of electronic health (eHealth) technologies, which are helping to improve both access to and the quality of health care services. As the Internet is now readily accessible through smart mobile devices, most people can take advantage of eHealth apps. The development of digital applications and remote communication technologies for patients with MS has increased rapidly in recent years. These apps are intended to complement traditional in-clinic approaches and can bring significant benefits to both patients with MS and health care providers (HCPs). For patients, such eHealth apps have been shown to improve outcomes and increase access to care, disease information, and support. These apps also help patients to participate actively in self-management, for example, by tracking adherence to treatment, changes in bladder and bowel habits, and activity and mood. For HCPs, MS eHealth solutions can simplify the multidisciplinary approaches needed to tailor MS management strategies to individual patients; facilitate remote monitoring of patient symptoms, adverse events, and outcomes; enable the efficient use of limited resources and clinic time; and potentially allow more timely intervention than is possible with scheduled face-to-face visits. These benefits are important because MS is a long-term, multifaceted chronic condition that requires ongoing monitoring, assessment, and management. We identified in the literature 28 eHealth solutions for patients with MS that fall within the four categories of screening and assessment, disease monitoring and self-management, treatment and rehabilitation, and advice and education. We review each solution, focusing on any clinical evidence supporting their use from prospective trials (including ASSESS MS, Deprexis, MSdialog, and the Multiple Sclerosis Performance Test) and consider the opportunities, barriers to adoption, and potential pitfalls of eHealth technologies in routine health care.
\end{abstract}

(JMIR Rehabil Assist Technol 2018;5(1):e5) doi: 10.2196/rehab.7805

\section{KEYWORDS}

communication; eHealth; technology; multiple sclerosis; telehealth; telemedicine; telerehabilitation 


\section{Introduction}

Multiple sclerosis (MS) is a chronic disease in which patients' physical and cognitive abilities often worsen progressively [1]. As well as having to come to terms with these clinical changes, patients frequently find that MS has an impact on social aspects of their lives and those of family members. It is very difficult for a single clinician to manage all areas of the disease; consequently, a multidisciplinary approach is advocated, involving a team of health care professionals (HCPs). To reduce the burden of MS, management strategies must be tailored to individual patients and include multidisciplinary assessment, services, rehabilitation, and appropriate treatment [2].

Important limitations of existing management strategies in chronic diseases such as MS are that clinical evaluation is cross-sectional at particular times, requiring patients to attend regular follow-up visits in MS clinics and comprehensive assessments to be undertaken. Ideally, this should happen at 6or 12-month intervals, but even at this frequency, mild relapses and disease progression may go unreported. Although more frequent personal consultation could improve disease monitoring, this is probably precluded by time, cost, and geographical constraints. Furthermore, with median survival being as high as 78.6 years in women with MS [3], patients commonly require long-term, multidisciplinary care in both clinical and community settings $[1,4]$. Despite recent advances in MS care, the availability of expert medical and rehabilitation services may be limited or such services may not be regularly provided owing to a lack of health care reimbursement. Furthermore, many patients cannot access available services because of restricted mobility, fatigue, or travel costs [5-7]. The ability of patients to attend multiple sessions of personalized rehabilitation for specific indications can be constrained by these factors, and long in-patient stays, if necessary, are costly and not widely available. In brief, there are significant implications for patients, their caregivers, and physicians in terms of access to, and provision of, MS health care services $[1,4]$.

Electronic health (eHealth) may help to address some of these issues. It has been defined as "an emerging field in the intersection of medical informatics, public health and business, referring to health services and information delivered or enhanced through the Internet and related technologies" [8]. As a subcategory of eHealth, telehealth is of particular note and is defined as "the use of information and communication technologies as a medium for the provision of rehabilitation services to sites or patients who are at a distance from the provider" [1]. eHealth technologies can improve access to health care resources and information by reducing barriers of distance, time, and cost; they can also be deployed to educate and support patients and caregivers in ongoing self-management and to empower patients to become more actively involved in the management and treatment of their disease (Figure 1) [1,9]. Among these, it may be some time before technologies for remote self-monitoring of blood markers in MS are available, but they would be useful. For example, blood tests to monitor disease status in MS form an increasingly important part of disease management, with a requirement for fortnightly monitoring of liver enzyme levels in patients with MS taking teriflunomide. From a service-provider perspective, adoption of such technologies may lead to more efficient use of resources and clinic time, and provide opportunities for monitoring interventions, tracking adverse events, and optimizing therapy that would not be possible with traditional face-to-face approaches alone [1,9].

Many eHealth solutions have been shown to be effective in improving outcomes, in facilitating remote monitoring of symptoms, and in increasing patient engagement, treatment adherence, and access to services and information in chronic diseases such as type 1 diabetes [10] and asthma [11], and in neurological conditions including Parkinson disease [12], suggesting that they may also be effective in MS. Furthermore, by generating prospective, longitudinal, real-world data, eHealth solutions may yield valuable insights into MS disease progression, such as symptoms indicative of relapse. This could also facilitate characterization of different MS disease phenotypes that have been reclassified in recent years to take account of observable active disease [13]. Characterizing a patient's MS phenotype correctly is crucial, as it impacts directly on decision making regarding treatment.

Opportunities to deploy eHealth have increased significantly in recent years, largely owing to technological advances in mobile communications. For example, at the start of 2017, more than half of the world's population was using smartphones, nearly two-thirds of the world's population possessed mobile phones, and more than half of the world's Web traffic came from mobile phones [14], meaning that many people now have the opportunity to engage with eHealth solutions. A high level of Internet usage among patients with MS has been reported; a survey in 2011 of more than 8500 patients with MS in North America and Canada noted that about $90 \%$ of those who responded had access to the Internet or email, and about two-thirds used these at least once daily [15]. Although the situation is unclear among MS physicians specifically, surveys in 2010 and 2013 highlighted a dramatic increase in social media usage from $42 \%$ [16] to 75\% [17] among practicing physicians in general. Ostensibly, both patients and physicians would seem receptive to the adoption of eHealth solutions. 
Figure 1. Electronic health (eHealth) technologies and health care. HCP: health care professional.

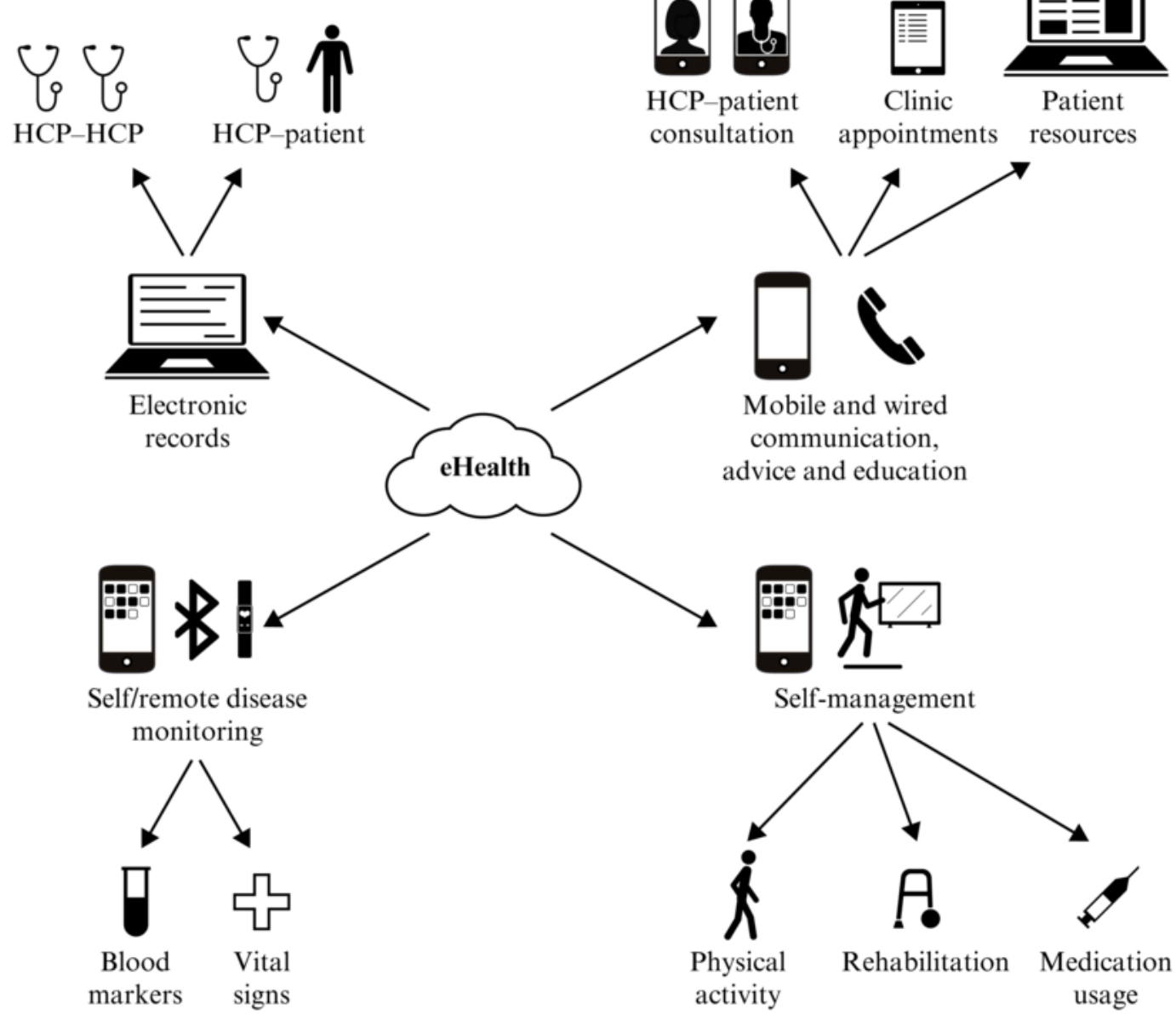

Although the definition of eHealth can include traditional telephone use, our review will focus on more recent technologies [18] such as the Internet, mobile devices, and apps. The digital and remote technologies developed for individuals with MS that are identified and discussed here pertain to one of four categories: screening and assessment, disease monitoring and self-management, treatment and rehabilitation, and advice and education. There are some overlaps among these four groupings, but they serve to simplify the task of assessing the eHealth landscape and also align broadly with categories used in a recent comprehensive review examining these technologies in a range of clinical conditions [19]. We provide a narrative synthesis of previously published information obtained through a targeted literature search and informed by our personal experience and describe various eHealth solutions, summarizing the clinical evidence supporting their feasibility and use in patients with MS. This review presents a broad perspective on eHealth, a fast-developing field, providing a useful resource to stimulate improved multidisciplinary research projects and services. It will aid HCPs who are interested in integrating eHealth solutions within their clinical practice, offering patients a convenient summary of technologies that have been evaluated clinically, and perhaps helping those developing eHealth solutions in MS to broaden their knowledge of the field. Moreover, the review highlights the need for evaluation of eHealth solutions in MS both in phase 3 clinical trials and in large patient cohorts in real-world settings.

\section{Screening and Assessment}

Few studies have examined the use of digital technologies as MS screening or assessment tools, but they have demonstrated that these technologies provide an efficient alternative to traditional clinic-based methods and are sensitive to capturing important disease information (Table 1). The Multiple Sclerosis Performance Test (MSPT) is a tablet-based app developed to overcome the challenges associated with measuring MS-related disability accurately [20]. The app builds on the assessments in the MS Functional Composite instrument, tracking and providing precise quantitative data on balance, walking speed, visual function, manual dexterity, and cognitive information-processing speed [20]. These outcomes are calculated automatically, and gathering such quantitative performance data provides an opportunity to perform in-depth post-hoc analyses of performance patterns. For example, it is possible to gain insights about whether manual dexterity abnormalities are related to grasping, transporting, or releasing [21]. In a prospective clinical validation study that enrolled 51 patients with MS and 49 healthy individuals, data captured with the MSPT app compared favorably with those captured by technicians, and patients reported a high level of acceptance of the tool [20]. The MSPT can be distributed readily to nonexpert clinicians in rural settings and could be adapted for use in patients' homes, yielding valuable assessment data collected by the patients themselves. 
Table 1. Digital and remote technologies in multiple sclerosis (MS): screening and assessment. BLCS: Bladder Control Scale; BWCS: Bowel Control Scale; CSI: Cognitive Stability Index; EDSS: Expanded Disability Status Scale; HCP: health care professional; MSPT: Multiple Sclerosis Performance Test; PASAT: Paced Auditory Serial Addition Test; TaDiMuS: Tablet-based Data capture in Multiple Sclerosis.

\begin{tabular}{|c|c|c|c|c|c|c|}
\hline Tool & Study design & Number of participants & Patient characteristics & Outcomes or applications & $\begin{array}{l}\text { Duration of } \\
\text { recording }\end{array}$ & Conclusions \\
\hline MSPT [20] & Prospective & $\begin{array}{l}\text { MSpatients: 51; } \\
\text { Healthy controls: } 49\end{array}$ & $\begin{array}{l}\text { Age in years, mean } \\
\text { (SD): } 46.2(10.1) ; \\
\text { EDSS, mean (SD): } 3.9 \\
\text { (1.8); Disease duration } \\
\text { in years, mean (SD): } \\
12.1(9.1)\end{array}$ & $\begin{array}{l}\text { Five performance modules } \\
\text { performed by each partici- } \\
\text { pant: Walking Speed Test, } \\
\text { balance test, Manual Dex- } \\
\text { terity Test, Processing } \\
\text { Speed Test, and Low-Con- } \\
\text { trast Letter Acuity versus } \\
\text { technician testing }\end{array}$ & $\begin{array}{l}\text { Tests repeated } \\
\text { twice by each } \\
\text { participant } \\
\text { during } 1 \text { day }\end{array}$ & $\begin{array}{l}\text { MSPT scores were } \\
\text { highly repro- } \\
\text { ducible, correlated } \\
\text { strongly with tech- } \\
\text { nician-adminis- } \\
\text { tered test scores, } \\
\text { discriminated MS } \\
\text { from healthy con- } \\
\text { trols and severe } \\
\text { from mild MS, and } \\
\text { correlated with pa- } \\
\text { tient-reported out- } \\
\text { comes. Measures } \\
\text { of reliability, sensi- } \\
\text { tivity, and clinical } \\
\text { meaning for MSPT } \\
\text { scores were favor- } \\
\text { able compared } \\
\text { with technician- } \\
\text { based testing. }\end{array}$ \\
\hline
\end{tabular}

\begin{tabular}{|c|c|c|c|}
\hline $\begin{array}{l}\text { ASSESS MS } \\
\text { (Microsoft, } \\
\text { Washington, } \\
\text { USA; Novartis } \\
\text { International } \\
\text { AG, Basel, } \\
\text { Switzerland) }\end{array}$ & Prospective & $\begin{array}{l}\text { MS patients: 51; Physi- } \\
\text { cians: } 12\end{array}$ & $\begin{array}{l}\text { Age in years, mean } \\
\text { (range): } 46.0 \text { (23-73); } \\
\text { EDSS, mean (range): } \\
3.0(1.0-7.0) \text {; Duration } \\
\text { of symptoms in years, } \\
\text { mean (range): } 14.2 \\
(0.5-47.0)\end{array}$ \\
\hline
\end{tabular}

[22]

Internet-admin- Prospective MS patients: 40 istered CSI

(Headminder

Inc, New York,

USA) $[23,24]$

TaDiMuS [25] Pilot

MS patients: $157 \quad$ Not reported (SD): 45 (10.2); Time
Classification of motor dysfunction in MS

Age in years, mean since diagnosis in years, mean (SD): 10 (7.4)
Measurement of cognitive function over the Internet

Tests complet- ASSESS MS is used by a HCP able and acceptable within a week to both patients (most on a sin- and HCPs, generatgle day) ing data of a quality suitable for clinical analysis.

PASAT administered 6 times, the score from the last test recorded, then CSI administered. At 14 days, NPsych administered but blinded to PASAT or CSI data.

Bladder Control Scale BLCS; Bowel Control 13 months Scale BWCS

Compared with NPsych, CSI showed $83 \%$ sensitivity and $86 \%$ specificity in detecting cognitive impairment, and PASAT showed $28 \%$ sensitivity and $86 \%$ specificity.

The mean time
taken to complete
the BLCS and
BWCS was $56.6 \mathrm{~s}$
and $39.3 \mathrm{~s}$, respec-
tively. A total of
184 continence test
sets (BLCS and
BWCS) were com-
pleted; an electron-
ic referral for for-
mal continence re-
view was automati-
cally generated 128
times (68.8\%) in
108 patients
(68.8\%), when
scores $\geq 2$ in the
BLCS or BWCS
were achieved.


Another tool, ASSESS MS, which captures depth videos (video images in which each pixel has a three-dimensional, 3D, position) of movement, is under evaluation for the assessment of motor dysfunction in MS within the clinical setting [22]. In a prospective, mixed-methods study that included six neurologists (mean MS experience: 4.3 years) and six nurses (mean MS experience: 2.7 years), ASSESS MS was used to record a predefined set of standard movements in 51 patients [22]. The tool was found to be usable by, and acceptable to, both patients and HCPs, and generated data of sufficient quality for clinical analysis. The tool may also improve accuracy when determining the Expanded Disability Status Scale (EDSS) score [26] by reducing subjectivity, for example, when rating tremor severity during the finger-nose test. Like the MSPT, ASSESS MS is currently at an early stage of development and is used only under the supervision of trained HCPs in a clinical setting, but the potential exists for its adoption in remote eHealth apps.

Although the physician-administered EDSS [26] is the current gold standard for monitoring MS disease severity [27], a patient-administered version could help to capture such data remotely in settings where patients cannot undergo regular physician assessment [27]. With this in mind, a pilot study was conducted [27] that compared an Internet-based version of the telephone-based EDSS [28] with the original physician-administered EDSS [26]. Overall patient satisfaction with the Web-based version was high, and results from it correlated well with those from the physician-administered version [27]. Although further studies are needed to validate the Internet-based tool, these findings suggest it will be invaluable in future long-term monitoring of patients with MS [27].

The heterogeneous nature of MS can make it challenging to measure patients' cognitive impairment, and it can be time-consuming and expensive to conduct a full battery of neurocognitive tests. Accordingly, an MS-center study enrolled 40 patients with clinically definite MS and subjective cognitive complaints [23] to examine whether cognitive function could be measured remotely using the Internet-administered Cognitive Stability Index (CSI) [24]. The study found the CSI to be as specific as, and more sensitive than, other tools typically used to assess cognitive function in MS, including the neuropsychological battery of tests NPsych and the Paced Auditory Serial Addition Test [23].

Sphincter dysfunction is common in MS [29], but bladder and bowel incontinence can be underreported and poorly managed $[25,30]$. Furthermore, the use of existing continence-screening tools may be limited in practice by time constraints and physician workload [25]. To address these issues, a cross-platform tool (Tablet-based Data capture in Multiple Sclerosis, TaDiMuS) was developed for use by patients on a tablet computer [25]. In a pilot study, 157 patients completed the TaDiMuS versions of the Bladder Control Scale and the Bowel Control Scale from the MS Quality of Life Inventory [31] while waiting for their appointments (data were captured wirelessly from the waiting room). Scores of $\geq 2$ on either questionnaire generated an automated electronic referral to the clinic's MS continence nurse [25]. The study confirmed the validity of TaDiMuS as a continence-screening tool, offering physicians an efficient, sensitive, and feasible method of screening patients for bladder and bowel dysfunction [25].

\section{Disease Monitoring and Self-Management}

Many tools have been developed to facilitate disease monitoring and self-management (Table 2). A major challenge facing physicians and patients with MS is how to organize, integrate, and interpret medical data to track disease progression, predict outcomes, and personalize treatment [32]. Accordingly, the University of California, San Francisco, CA, USA developed MS BioScreen, a tablet-based navigation system that integrates data from a patient's medical records with population-based data to inform physicians about their disease trajectory relative to reference populations and to guide the patient and physician in treatment decisions [32-34]. 
Table 2. Digital and remote technologies in multiple sclerosis (MS): disease monitoring and self-management. EDSS: Expanded Disability Status Scale; MS-HAT: Multiple sclerosis—specific version of Home Automated Telemanagement; MSDS3D: Multiple Sclerosis Documentation System: Three-Dimensional; MSRS-R: Multiple Sclerosis Rating Scale-Revised; N/A: not applicable; RMSS: relapsing-remitting multiple sclerosis; RC: routine care.

\begin{tabular}{|c|c|c|c|c|c|c|}
\hline Tool & Study design & Number of participants & Patient characteristics & Outcomes or applications & $\begin{array}{l}\text { Duration of } \\
\text { recording }\end{array}$ & Conclusions \\
\hline $\begin{array}{l}\text { MS BioScreen } \\
\text { (University of } \\
\text { California San } \\
\text { Francisco MS } \\
\text { Centre, San } \\
\text { Francisco, } \\
\text { USA) [32-34] }\end{array}$ & N/A & N/A & N/A & $\begin{array}{l}\text { Integrate patient informa- } \\
\text { tion; analyze disease } \\
\text { course; facilitate patient } \\
\text { engagement }\end{array}$ & N/A & N/A \\
\hline $\begin{array}{l}\text { MSDS3D } \\
{[35,36]}\end{array}$ & N/A & N/A & N/A & $\begin{array}{l}\text { Electronic patient-manage- } \\
\text { ment system that integrates } \\
\text { MS registry data }\end{array}$ & N/A & N/A \\
\hline $\begin{array}{l}\text { MSmonitor } \\
\text { (Curavista } \\
\text { Health, } \\
\text { Geertruiden- } \\
\text { berg, Nether- } \\
\text { lands) [37] }\end{array}$ & $\begin{array}{l}\text { Web-based } \\
\text { survey }\end{array}$ & $\begin{array}{l}\text { MS patients: } 55^{\mathrm{a}} \text {; } \\
\text { RMSS: } 38 \text {; secondary } \\
\text { progressive MS: } 11 ; \\
\text { primary progressive } \\
\text { MS: } 4 \text {; clinically isolat- } \\
\text { ed syndrome: } 1\end{array}$ & $\begin{array}{l}\text { Mean age }(\mathrm{SD}) \text { in } \\
\text { years: } 46.3(11.8)\end{array}$ & $\begin{array}{l}\text { Utilization and meaningful- } \\
\text { ness of the program's ele- } \\
\text { ments, perceived use of } \\
\text { data by neurologists and } \\
\text { nurses, and appreciation of } \\
\text { care, self-management, } \\
\text { and satisfaction }\end{array}$ & $\begin{array}{l}\text { Data collec- } \\
\text { tion: January } \\
\text { 2013 to April } \\
\text { 2013; Survey } \\
\text { time: } 20 \text { min }\end{array}$ & $\begin{array}{l}\text { In } 46 \%(25 / 55) \text { of } \\
\text { the respondents, the } \\
\text { insight into their } \\
\text { symptoms and dis- } \\
\text { abilities increased. } \\
\text { The overall satisfac- } \\
\text { tion with the pro- } \\
\text { gram was } 3.5 \text { out of } \\
5 \text {, and } 73 \% \text { (40/55) } \\
\text { of the respondents } \\
\text { would recommend } \\
\text { the program to other } \\
\text { persons with MS. }\end{array}$ \\
\hline $\begin{array}{l}\text { move II (Mo- } \\
\text { visens GmbH, } \\
\text { Karlsruhe, } \\
\text { Germany) } \\
{[38]}\end{array}$ & Pilot & MS patients: 11 & $\begin{array}{l}\text { Mean (SD) age, in } \\
\text { years: } 41.0(9.3) . \text { Mean } \\
\text { (SD) disease duration, } \\
\text { in years: } 12.2(10.7) ; \\
\text { EDSS 1.0-2.5: } \mathrm{n}=6 ; \\
\text { EDSS 3.0-5.0: } \mathrm{n}=5\end{array}$ & Activity parameters & $\begin{array}{l}\text { Measurements } \\
\text { collected } 4 \\
\text { times, each } \\
\text { time lasting } \\
10 \text { days and } \\
\text { separated by } 3 \\
\text { months. }\end{array}$ & $\begin{array}{l}\text { Changes in physical } \\
\text { ambulatory activity } \\
\text { were captured. } \\
\text { move II was more } \\
\text { responsive to slight } \\
\text { disability changes } \\
\text { than the clinical } \\
\text { measures. }\end{array}$ \\
\hline $\begin{array}{l}\text { MSRS-R (Pa- } \\
\text { tientsLikeMe } \\
\text { Inc Cam- } \\
\text { bridge, MA, } \\
\text { USA) [39] }\end{array}$ & Pilot & RRMS patients: 816 & $\begin{array}{l}\text { Mean (SD) age, in } \\
\text { years: } 45.9(9.8) \text {; mean } \\
(\mathrm{SD}) \text { time since diagno- } \\
\text { sis, in years: } 6.6(6.6)\end{array}$ & $\begin{array}{l}\text { Measure of MS-related } \\
\text { functional disability }\end{array}$ & $\begin{array}{l}\text { 2-hour cogni- } \\
\text { tive interview; } \\
\text { Web-based } \\
\text { survey }\end{array}$ & $\begin{array}{l}\text { The MSRS-R exhib- } \\
\text { ited high internal } \\
\text { consistency (Cron- } \\
\text { bach alpha=.86), } \\
\text { correlated highly } \\
\text { with existing instru- } \\
\text { ments, (patient-deter- } \\
\text { mined disease steps, } \\
\rho=.84 \text {; Multiple } \\
\text { Sclerosis Walking } \\
\text { Scale-12, } \rho=.83 \text { ) pa- } \\
\text { tient-determined dis- } \\
\text { ease stage and re- } \\
\text { lapse burden in the } \\
\text { last } 2 \text { years. It assess- } \\
\text { es a number of dis- } \\
\text { ability-related do- } \\
\text { mains, while mini- } \\
\text { mizing patient bur- } \\
\text { den. }\end{array}$ \\
\hline $\begin{array}{l}\text { SymTrac (No- } \\
\text { vartis Interna- } \\
\text { tional AG, } \\
\text { Basel, } \\
\text { Switzerland) } \\
\text { [40] }\end{array}$ & N/A & N/A & N/A & $\begin{array}{l}\text { Track general well-being } \\
\text { and symptoms over time }\end{array}$ & N/A & N/A \\
\hline
\end{tabular}




\begin{tabular}{|c|c|c|c|c|c|c|}
\hline Tool & Study design & Number of participants & Patient characteristics & Outcomes or applications & $\begin{array}{l}\text { Duration of } \\
\text { recording }\end{array}$ & Conclusions \\
\hline $\begin{array}{l}\text { My MS Man- } \\
\text { ager (Multiple } \\
\text { Sclerosis Asso- } \\
\text { ciation of } \\
\text { America, } \\
\text { Cherry Hill, }\end{array}$ & N/A & N/A & N/A & $\begin{array}{l}\text { Track disease activity; } \\
\text { store medical information; } \\
\text { generate charts and reports } \\
\text { across various metrics such } \\
\text { as treatments, moods, and } \\
\text { symptoms }\end{array}$ & N/A & N/A \\
\hline
\end{tabular}

NJ, USA;

@Point of

Care, Liv-

ingston, $\mathrm{NJ}$,

USA) [41]

\begin{tabular}{|c|c|c|c|c|c|c|}
\hline $\begin{array}{l}\text { MSdialog } \\
\text { (Merck } \\
\text { Serono, Darm- } \\
\text { stadt, Ger- } \\
\text { many) [42] }\end{array}$ & Pilot & MS patients: 42 & $\begin{array}{l}\text { Mean (SD) age in } \\
\text { years: } 43.9(7.6) \text {; mean } \\
\text { (SD) time since diagno- } \\
\text { sis, years: } 7.0(6.4) \text {; } \\
\text { mean (SD) duration of } \\
\text { drug treatment, years: } \\
4.8(4.5)\end{array}$ & $\begin{array}{l}\text { Health-tracking tool, data } \\
\text { from which can be shared } \\
\text { with health care providers }\end{array}$ & 6 weeks & $\begin{array}{l}82 \%(32 / 39) \text { of pa- } \\
\text { tients considered } \\
\text { MSdialog better than } \\
\text { previous methods } \\
\text { for tracking their } \\
\text { health, and } 95 \% \\
\text { (37/39) would recom- } \\
\text { mend its use. }\end{array}$ \\
\hline
\end{tabular}

MS Journal N/A N/A N/A Nssist with injections N/A

(Tensai Solu-

tions LLC,

CA, USA)

[43]

myBETAapp
(Bayer AG,

N/A

N/A

Schedule, track, and record N/A

N/A

Leverkusen,

Germany)

[44]

MS-HAT [45] Randomized MS patients: 30; RC: 13; MS-HAT: 17
Mean age (SD) in years-RC: 44.0 (11.8) MS-HAT: 51.0 (9.2).

Mean (SD) time since

MS onset, in years-RC: 11.9 (9.8); MS-HAT: 18.1 (13.4). Median EDSS

(range)-RC: 3.0 (2.0-

8.0); MS-HAT: 3.5

(2.0-8.0)

MySupport Retrospec- MS patients; MySup- Not reported program (Mer- tive ck Serono,

Darmstadt,

Germany)

[46] port: 604; RC: 2461
Persistence with interferon 24 months $\beta$-1a therapy

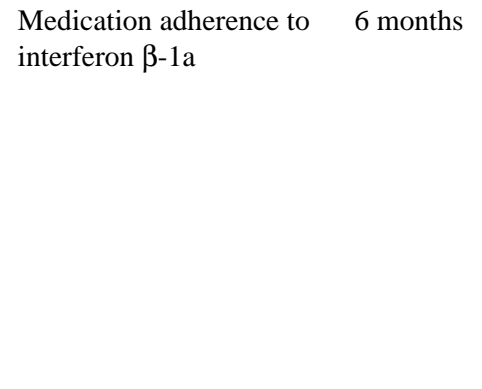

Medication adherence to 6 months interferon $\beta$-1a

(1) 
therapeutic processes, thus improving patient care and representing an excellent resource for data mining [35,36].

A separate tool, MSmonitor, is an interactive, Internet-based program for the self-monitoring, self-management, and integrated multidisciplinary care of patients with MS [47]. The original content comprised (1) questionnaires to assess the impact of MS and related quality of life (QoL), fatigue, anxiety, and depression; (2) inventories to capture medication, adherence, and urological symptom data; (3) diaries to record activity, rest periods, micturition, and fluid intake; (4) an e-consult functionality to enable patients to contact their physician; and (5) an $e$-logbook [47]. Pilot data suggested that repeated use of MSmonitor led to an increase in health-related QoL and helped patients to self-manage fatigue [47]. In a subsequent survey of 55 patients with MS, MSmonitor has been shown to improve patients' insights into symptoms and disabilities and improve the quality of nursing care they received [37].

Ambulation is one aspect of physical disability on which the EDSS assessment focuses, particularly at advanced stages of disease. Abnormalities in spatiotemporal parameters that affect walking ability can present in the early stages of MS, and habitual walking performance is sensitive to disease progression and correlates highly with clinical tests of walking capacity and with EDSS score. As such, recording daily activity is considered important for tracking disability progression [48]. A pilot study testing a portable activity-monitoring sensor, designed to gather data on home-based, physical activity (PA) in 11 patients with MS, showed that a simple 3D accelerometer (move II) could track fluctuations in daily PA and also tracked disability changes better than EDSS scores [38]. If this finding can be reproduced in a larger group of patients, it may be possible to use the accelerometer to detect signs of worsening disability earlier than when using standard in-clinic measures [38]. Similarly, a study performed in eight patients with MS has demonstrated how data from wireless pressure sensors in patients' shoes can be combined with Web-based software and mobile technology to detect early signs of deterioration in gait, enabling physicians to intervene rapidly. Data collected were accessible to doctors, patients, and administrators via a Web app [49]. A further study also demonstrated the feasibility of using accelerometers and a multimedia platform to monitor walking function remotely in 25 patients with MS (EDSS score 1.0-6.0) over 2 years and the potential of this approach to capture changes that may indicate deterioration over time [50].

To improve the assessment of functional status in patients with MS, a new patient-reported rating scale, the Multiple Sclerosis Rating Scale-Revised (MSRS-R), was developed, refined, and validated using the Web-based data platform, PatientsLikeMe [39,51]. The MSRS-R was developed to capture disability-related information across a range of domains, rather than focusing on ambulation alone. The MSRS-R exhibits desirable psychometric properties and correlates with existing measures, with the advantage of being more concise than other measures and therefore less burdensome for the patient to complete. Potentially, the MSRS-R, in conjunction with PatientsLikeMe, could provide a valuable source of real-world evidence, encompassing demographic, social networking, treatment, and symptom data [39].

Many apps have been developed to support MS symptom monitoring and disease tracking, but, to date, few have been the subject of published studies. Relapses may not always be tracked because patients forget to report them or because they are not recorded in a patient's notes. Underreporting of relapses may mean that patients are not receiving the most appropriate treatment, so an app has been developed to address this issue. The Novartis SymTrac app helps to identify when relapses occur by prompting patients to monitor their symptoms and well-being over time, logging information that can be sent automatically to physicians as needed [40,52].

The MS Association of America developed the app My MS Manager for storing medical information, tracking disease activity, generating private reminders, and connecting patients with physicians to share details of their progress [41]. The MSdialog app [53] is an Internet- and mobile-based app designed to capture remote data on clinical and patient-reported outcomes and on self-administration of interferon $\beta$-1a [42]. Data from the app are combined with information captured by RebiSmart, an adjustable electronic injection device [53,54]. The app allows patients to create their own health reports and share the information with their physicians. It also tracks trends in treatment adherence and health, and has a reminder function for medication administration and future appointments [53]. In a 6-week pilot study evaluating the app, patients $(n=42)$ found it easy to use and to be superior to their previous health-tracking methods that were mostly handwritten [42].

Nonadherence to MS medications is common and is associated with a number of costs, but monitoring adherence can be challenging, time-consuming, and expensive [45,55]. In addition to the MSdialog app [53], the MSJournal app [43] and myBETAapp [44] have been developed to help patients and caregivers to track injections and injection-site history and to set reminder alerts for injections $[43,44]$. To test whether telehealth technologies could help to monitor or modify adherence, a study examined adherence to weekly interferon $\beta$-1a and daily vitamin $\mathrm{D}$ among patients randomized to routine care or to the use of an MS-specific version of the Internet-based Home Automated Telemanagement (HAT) system (MS-HAT) [45]. For 6 months, 30 patients with MS randomized to MS-HAT received text or email reminders to administer injections and a weekly probe asking when they had taken their vitamin D supplements [45]. Although, overall, no major improvements in medication adherence were reported with the MS-HAT system versus routine care, 4 patients (two using MS-HAT and two on routine care) discontinued therapy and did not alert their physicians to their decision: the MS-HAT system detected the discontinuations, allowing timely physician intervention. 
Table 3. Digital and remote technologies in multiple sclerosis (MS): treatment and rehabilitation. ADL: activities of daily living; BDI: Beck Depression Inventory; EDSS: Expanded Disability Status Scale; GEMS: Guidelines for Exercise in Multiple Sclerosis; HAT: Home Automated Telemanagement; MACFIMS: Minimal Assessment of Cognitive Function in Multiple Sclerosis; MAPSS-MS: Memory, Attention and Problem-Solving Skills for Persons with Multiple Sclerosis; RMSS: relapsing-remitting multiple sclerosis; RC: routine care; tDCS: transcranial direct current stimulation.

\begin{tabular}{|c|c|c|c|c|c|c|}
\hline Tool & Study design & Number of participants & Patient characteristics & Outcomes or applications & $\begin{array}{l}\text { Duration of } \\
\text { recording }\end{array}$ & Conclusions \\
\hline HAT [56] & Pilot & MS patients: 12 & Not reported & $\begin{array}{l}\text { Symptom tracking, patient } \\
\text { education, exercise regi- } \\
\text { men instruction and moni- } \\
\text { toring }\end{array}$ & 12 weeks & $\begin{array}{l}\text { Statistically signifi- } \\
\text { cant improvement in } \\
\text { a timed } 25 \text {-foot } \\
\text { walk, 6-min walk, } \\
\text { and Berg Balance } \\
\text { Scale compared with } \\
\text { baseline. Patients } \\
\text { were highly satisfied } \\
\text { with the service. }\end{array}$ \\
\hline $\begin{array}{l}\text { MAPSS-MS } \\
\text { program [57] }\end{array}$ & $\begin{array}{l}\text { Randomized } \\
\text { controlled sin- } \\
\text { gle-blind }\end{array}$ & $\begin{array}{l}\text { MS patients: } 61 \text {; } \\
\text { MAPSS-MS: } 34 \text {; Con- } \\
\text { trol: } 27\end{array}$ & $\begin{array}{l}\text { Mean (SD) age in } \\
\text { years: } 47.95(8.76)\end{array}$ & $\begin{array}{l}\text { MACFIMS and self-report } \\
\text { instruments (use of memo- } \\
\text { ry strategies, self-efficacy } \\
\text { for control of MS, and } \\
\text { neuropsychological compe- } \\
\text { tence in ADL) at baseline } \\
\text { and after intervention at } 2 \\
\text { and } 5 \text { months }\end{array}$ & 8 weeks & $\begin{array}{l}\text { Both groups im- } \\
\text { proved significantly } \\
\text { over time on most } \\
\text { measures in the } \\
\text { MACFIMS battery, } \\
\text { as well as the mea- } \\
\text { sures of strategy use } \\
\text { and neuropsycholog- } \\
\text { ical competence in } \\
\text { ADL. }\end{array}$ \\
\hline
\end{tabular}

Computerized Randomized specific train- controlled ing [58] double-blind

Home eTrain- Randomized ing [59] controlled

MS patients: 18; e-

Mean (range) age in

raining: 9; Hippotherapy: 9

attention-specific train- years: $40.9(11.5)$;

ing: 63 ; nonspecific

training: 39

mean (SD) disease dur

tion in years: 13.0 (8.7) mean (SD) for EDSS:

$2.7(1.5)$

Neuropsychological assess- 3 months ment, depression, fatigue,

everyday activities, and at-

tentive performance$$
\text { (1.5) }
$$

ears: 45.5 (32-57); mean (range) for EDSS:

3.8 (2-6); mean (range) disease duration in years: $19.0(1-35)$

COGNIPilot

TRAcK (Italian Multiple

Sclerosis

Foundation,

Genoa, Italy)

[60]
Mean (SD) age in years: 49.1 (9.1); mean (SD) for EDSS: 3.8 (1.9); mean (SD) disease duration (months): 161.7 (109.6)
Static and dynamic balance 12 weeks

\section{Usability, motivation to} use, and compliance to treatment

8 weeks
A benefit with attention-specific training was observed on the Paced Auditory Serial Addition Test $(P<.002)$. However, patient self-reported outcomes did not reveal differences between the training groups.

Both interventions demonstrated similar and significant improvement in static and dynamic balance capacity.

Adherence was $84 \%$ (33.4/40). A total of $100 \%(16 / 16)$ of patients felt independent to use the app at home, $75 \%$ $(12 / 16)$ found the exercises interesting, and $81 \%(13 / 16)$ found the exercises useful and were motivated to use the app again. 


\begin{tabular}{|c|c|c|c|c|c|c|}
\hline Tool & Study design & Number of participants & Patient characteristics & Outcomes or applications & $\begin{array}{l}\text { Duration of } \\
\text { recording }\end{array}$ & Conclusions \\
\hline $\begin{array}{l}\text { Web Based } \\
\text { Physio [61] }\end{array}$ & $\begin{array}{l}\text { Randomized } \\
\text { controlled pi- } \\
\text { lot study }\end{array}$ & $\begin{array}{l}\text { MS patients: } 30 \text {; Inter- } \\
\text { vention: } 15 \text {; Control: } 25\end{array}$ & $\begin{array}{l}\text { Mean }(\mathrm{SD}) \text { age in } \\
\text { years: } 51.7(11.2) ; \\
\text { mean }(\mathrm{SD}) \text { time since } \\
\text { diagnosis (years): } 12.7 \\
(9.1) ; \text { mean }(\mathrm{SD}) \\
\text { EDSS: } 5.9(0.5)\end{array}$ & $\begin{array}{l}\text { Mobility, quality of life, } \\
\text { and anxiety or depression }\end{array}$ & 12 weeks & $\begin{array}{l}\text { No significant be- } \\
\text { tween-group differ- } \\
\text { ence in primary end- } \\
\text { point (timed } 25 \text {-foot } \\
\text { walk, } P=.17 \text { ) or oth- } \\
\text { er secondary end- } \\
\text { points except Multi- } \\
\text { ple Sclerosis Impact } \\
\text { Scale }(P=.048) \text {. Par- } \\
\text { ticipants found the } \\
\text { website easy to use, } \\
\text { convenient, and mo- } \\
\text { tivating, and were } \\
\text { happy to use it in the } \\
\text { future. }\end{array}$ \\
\hline
\end{tabular}
(University of controlled Invigor8: 23; RC: 17 Southampton, phase 2 trial Southampton, UK) [62]

GEMS [63]

Randomized, controlled pilot study (ongoing)

Deprexis (Gaia AG, Hamburg, Germany) [64]
Randomized, controlled phase 2 trial
MS patients: target re- N/A

cruitment: 30

MS patients: 90; De- $\quad$ Mean (SD) age prexis: 45 ; Waiting list 45

MS patients: 20

8.4 (7.6)

$$
\begin{aligned}
& \text { years-MS Invigor8: } \\
& 40.1 \text { (17.8); RC: } 41.8 \\
& \text { (11.4); RRMS } \\
& \text { (\%)-MS Invigor8: } \\
& \text { 43.5\% (10/23); RC: } \\
& \text { 71\% (12/17) }
\end{aligned}
$$

(years) -Deprexis: 45.4

(12.6); Waitlist: 45.2

(10.6); Disability, \%

patients with walking

ability $<500 \mathrm{~m}-$ De-

prexis: $51(23 / 45)$;

Waitlist: 49 (22/45).

Mean (SD) disease dura-

tion in years-Deprex-

is: 8.2 (7.3); Waitlist:

Remotely con- Pilot trolled tDCS

$[65,66]$ tigue, feasibility, and cost-

effectiveness

Efficacy and safety of a
home-based, exercise program

BDI 9 weeks

9 weeks

BDI scores decreased in the Deprexis group and increased in the control group (mean difference -4.02 points, $95 \% \mathrm{CI}$ -7.26 to -0.79 ; $P=.02)$.
Across a total of 192 supervised treatment sessions, no session required discontinuation, and no adverse events were reported.
Physicians were pleased to be able to monitor adherence more efficiently than via chart reviews or telephone calls. Furthermore, most patients found the system easy to use, wanted to continue using it after the study, and indicated that they would recommend it to others [45]. Similarly, in the industry-sponsored MySupport program, which provides telephone, text, and website access to patients prescribed interferon $\beta$-1a, a retrospective study of anonymized data from 604 patients in the Republic of Ireland found an increased probability of patients using MySupport remaining on treatment compared with a control group of 2461 patients receiving routine care [46].

\section{Treatment and Rehabilitation}

Various treatment and rehabilitation solutions are shown in Table 3. The Internet-based HAT system was designed for use in patients' homes to monitor symptoms and educate them about their condition [56]. It was also developed to provide step-by-step instructions on how to follow a tailored exercise regimen, to monitor exercise compliance, and to adapt the exercise regimen based on performance [56]. A 12-week pilot study that enrolled 12 patients with MS provided a preliminary demonstration of the feasibility of the HAT system and its potential for use on other devices such as tablets and mobile phones. Its ease of use and convenience were considered particularly beneficial for patients who may be reluctant or unable to visit a physician frequently [56].

The use of other home-based technologies has been explored in a variety of MS rehabilitation settings, including Internet- or computer-assisted training to enhance cognitive performance 
[57,67], attention [58], and balance, posture, and strength [59]. The Memory, Attention, and Problem Solving Skills for Persons with MS (MAPSS-MS) program is a computer-assisted cognitive rehabilitation intervention for enhancing cognitive function in patients with MS [57]. In the 8-week, single-blind, randomized controlled MAPSS-MS study involving 61 patients with MS, significant improvements in cognition were observed with the MAPSS-MS program, and it was found to be feasible to use and well accepted by patients [57]. COGNI-TRAcK, a self-administered cognitive training app, has also been shown to provide intensive and personalized cognitive rehabilitation $[60,68]$. In 16 patients with MS and cognitive impairment who underwent an 8-week intervention at home, COGNI-TRAcK was found to be highly usable, motivating, and well accepted by users [60]. COGNI-TRAcK was also evaluated in 28 patients with MS and cognitive impairment to determine the effects of adaptive versus nonadaptive cognitive training. Adaptive training involved increasing or decreasing the difficulty level of an exercise based on whether a participant completed preceding exercises correctly. COGNI-TRAcK was shown to be suitable for administering personalized training to patients with cognitive impairment. It also demonstrated that an adaptive work load is crucial for determining the effectiveness of cognitive treatment, with only patients in the adaptive group showing improvements in cognitive function on study and at 6-month follow-up [68].

A double-blind, randomized controlled study has evaluated a home-based computerized program for retraining attention dysfunction under the supervision of a caregiver in 102 patients with relapsing-remitting MS [58]. Compared with nonspecific training, the attention-dysfunction-specific training resulted in some improvements exclusively in tasks of sustained attention, although patient-reported outcomes did not reveal differences between the groups [58]. Balance was also shown to be improved using the Internet-based program Home eTraining. In a randomized controlled study that enrolled 18 patients with MS, eTraining demonstrated significant improvements in static and dynamic balance that were similar to those resulting from hippotherapy [59].

Home-based technologies have also been used for Web-based physiotherapy exercises [61,69], physical telerehabilitation [70], and physical-activity-targeted behavioral interventions [71,72]. Web Based Physio, developed by the University of Glasgow, Glasgow, United Kingdom, provides Web-based physiotherapy exercise programs personalized for individual patients with long-term conditions including MS, with the aim of allowing patients to self-manage their condition [69]. The effectiveness of this individualized, Internet-based physiotherapy program was evaluated in a 12-week randomized controlled pilot study in community-dwelling adults moderately affected by MS (EDSS score 5.0-6.5). Although there was no significant difference in the primary outcome measure (timed 25-foot walk), patients found the website easy to use, convenient, and motivating, and indicated a willingness to use it in the future. A fully powered, definitive randomized controlled trial is planned to determine the tool's effectiveness [61].

Another 12-week study assessed feasibility of use, patient acceptance, and magnitude of clinical benefit of home-based

http://rehab.jmir.org/2018/1/e5/ physical telerehabilitation in 12 individuals with MS (75\%, 9/12, had self-reported moderate MS) who received a tailored rehabilitative exercise program [70]. Home-based physical telerehabilitation was shown to significantly improve functional outcomes including walking and balance. Internet-delivered behavioral interventions have also demonstrated an increase in activity among patients with MS. A 3-month randomized controlled study evaluating an Internet-delivered and theory-based behavioral intervention that was supplemented with video coaching in 45 patients with MS showed a large increase in PA after 12 weeks that was sustained over 3 months [72].

Computer- or gaming-based systems, such as the Nintendo Wii Fit console or Kinect motion sensor, may offer the potential for telerehabilitation applications in patients with MS because patients enjoy these exercises and find them motivating [73]. Although some of these applications have demonstrated significant beneficial effects, the results of others have been mixed. For example, the Nintendo Wii platform appears to stimulate the postural control system only in the frontal plane and not the sagittal plane [74]. Thus, although available games are beneficial in some settings, they will be more effective if tailored to the type and severity of impairments present in individual patients with MS and adapted to offer Internet-assisted monitoring [74,75]. In general, the success of Nintendo Wii or exergaming technologies in randomized controlled clinical studies has also been mixed [76-78], but in a 24-week diffusion tensor imaging study, modifications in the microstructure of superior cerebellar peduncles were observed following 12 weeks of Nintendo Wii balance-board training [79]. These changes correlated with clinical improvements in participants' balance, suggesting that high-intensity, task-oriented exercises could induce favorable, myelin-related microstructural changes in the brains of patients with MS [79].

To address the potential issue of patients performing their rehabilitation exercises incorrectly, a comprehensive system is in development that combines weekly face-to-face clinic sessions with remotely supervised exercise training at home, using a Web-based platform and tracking tool that analyzes and corrects patients' positions in real time [80]. This tool is currently being validated, and preliminary results indicate that the system can be used effectively by patients and HCPs [80].

In light of the success of telephone-administered interventions for improving various MS-associated symptoms and QoL [81-85], several studies have examined (or will examine) whether interactive telehealth interventions can improve MS-associated anxiety, cognitive function, mood, fatigue, impact, pain, QoL, and sleep quality [62-64,86-90]. These include a Web-based self-help program (Deprexis) that combines cognitive behavioral therapy (CBT) with mobile platform and dialog technology and has proven efficacy in treating depression [64,91]; an Internet-based CBT program (MS Invigor8) administered with or without email support to help reduce fatigue symptoms [62,90]; MS-specific multimedia software that delivers a meditation course designed to decrease anxiety, depression, and fatigue, as well as improve quality of sleep and QoL [88]; the project Guidelines for Exercise in Multiple Sclerosis, an interactive, guidelines-based exercise program 
aimed at improving MS symptoms and QoL [63]; and physical exercise e-training programs that demonstrate positive and significant effects on muscle strength, lung function, and sports activity, but not on QoL or fatigue [92,93]. Perhaps the most robust of these studies was a 9-week randomized trial conducted in patients with MS who had self-reported depression symptoms $(\mathrm{N}=90)$ [64]. Patients received the intervention (Deprexis [91]) or remained on a waiting list (control) for 9 weeks, and over the course of the study, use of Deprexis significantly reduced Beck Depression Inventory scores, whereas scores increased in the control group. These results highlight the utility of Web-based intervention programs, especially for patients who cannot attend or do not like to participate in treatment sessions regularly [64].
Home-based, but clinician-supervised, technologies have also been examined, such as the remotely supervised self- or proxy-administration protocol for home delivery of transcranial direct current stimulation (tDCS) [65]. Across 192 supervised treatment sessions, remotely supervised protocol adherence was greater than that observed in clinic-based delivery studies. Furthermore, there were no reported discontinuations or adverse effects. Thus, remotely supervised tDCS could be used to expand patient access to this potential treatment option [65].

\section{Advice and Education}

Several apps have been developed to provide advice and education to individuals living with MS, including the MS Buddy app [94] and the MS self app, which, in addition to providing MS-related information, can synchronize with Fitbit devices (Table 4) [95].

Table 4. Digital and remote technologies in multiple sclerosis (MS): advice, support, and education. MCCO: Mellen Center Care Online; N/A: not applicable.

\begin{tabular}{|c|c|c|c|c|c|c|}
\hline Tool & Study design & Number of participants & Patient characteristics & Outcomes or applications & $\begin{array}{l}\text { Duration of } \\
\text { recording }\end{array}$ & Conclusions \\
\hline $\begin{array}{l}\text { MS Buddy } \\
\text { (Healthline Net- } \\
\text { works Inc., San } \\
\text { Francisco, USA) } \\
\text { [94] }\end{array}$ & N/A & N/A & N/A & $\begin{array}{l}\text { An app for discovering } \\
\text { support and getting advice } \\
\text { from an MS peer }\end{array}$ & N/A & N/A \\
\hline $\begin{array}{l}\text { MS self (Acorda } \\
\text { Therapeutics Inc., } \\
\text { New York, USA) } \\
\text { [95] }\end{array}$ & N/A & N/A & N/A & $\begin{array}{l}\text { An app designed to help } \\
\text { patients manage their MS }\end{array}$ & N/A & N/A \\
\hline $\begin{array}{l}\text { My MS Manager } \\
\text { (Multiple Sclerosis } \\
\text { Association of } \\
\text { America, Cherry } \\
\text { Hill, NJ, USA; } \\
\text { @ Point of Care, } \\
\text { Livingston, NJ, } \\
\text { USA) [41] }\end{array}$ & N/A & N/A & N/A & $\begin{array}{l}\text { Provides advice and sup- } \\
\text { port }\end{array}$ & N/A & N/A \\
\hline $\begin{array}{l}\text { Deprexis (Gaia } \\
\text { AG, Hamburg, } \\
\text { Germany) [64] }\end{array}$ & $\begin{array}{l}\text { Randomized, } \\
\text { controlled } \\
\text { phase } 2 \text { trial }\end{array}$ & $\begin{array}{l}\text { MS patients: } 90 \text {; De- } \\
\text { prexis: } 45 \text {; Waiting list: } \\
45\end{array}$ & $\begin{array}{l}\text { Mean (SD) age, in } \\
\text { years-Deprexis: } 45.4 \\
\text { (12.6); Waitlist: } 45.2 \\
\text { (10.6). Disability, } \% \\
\text { patients with walking } \\
\text { ability <500 m-De- } \\
\text { prexis: 51; Waitlist: } 49 \text {. } \\
\text { Mean (SD) disease dura- } \\
\text { tion, in years-Deprex- } \\
\text { is: } 8.2 \text { (7.3); Waitlist: } \\
8.4 \text { (7.6) }\end{array}$ & $\begin{array}{l}\text { Web-based psychoeduca- } \\
\text { tion; Beck Depression In- } \\
\text { ventory }\end{array}$ & 9 weeks & N/A \\
\hline $\begin{array}{l}\text { MCCO system } \\
\text { (Cleveland Clinic, } \\
\text { Cleveland, OH, } \\
\text { USA) [97] }\end{array}$ & $\begin{array}{l}\text { Randomized } \\
\text { controlled }\end{array}$ & $\begin{array}{l}\text { MS patients: 206; MC- } \\
\text { CO-original: } 104 \text {; MC- } \\
\text { CO-enhanced: } 102\end{array}$ & $\begin{array}{l}\text { Mean age (SD), } \\
\text { years-MCCO-origi- } \\
\text { nal: } 48.1 \text { (9.7); MCCO- } \\
\text { enhanced: } 48.1 \text { (9.1) } \\
\text { Mean Incapacity Status } \\
\text { Scale (SD)-MCCO- } \\
\text { original: } 12.3 \text { (9.2); } \\
\text { MCCO-enhanced: } 12.7 \\
\text { (8.2) }\end{array}$ & $\begin{array}{l}\text { Compare MCCO-original } \\
\text { versus MCCO-enhanced }\end{array}$ & 12 months & $\begin{array}{l}\text { No differences } \\
\text { in patient- or } \\
\text { physician-report- } \\
\text { ed outcomes } \\
\text { were reported. }\end{array}$ \\
\hline
\end{tabular}

The Mellen Center Care Online (MCCO) secure Internet-based portal was developed in 1998 to empower patients to participate more actively in their own health care [96,97]. It is designed to help address patients' concerns, enhance communication between patients and physicians, provide links to patient information about MS symptoms, and allow patients to monitor 
changes in their disease status and prepare for upcoming health care visits $[96,97]$. The system functionality was later expanded to include a self-monitoring and self-management component that allowed patients to assess their MS symptoms and receive graphical feedback and evaluate symptom changes to make decisions about how to respond to them [97]. Apps that have been developed for disease monitoring or rehabilitation also provide patient advice and support, including the My MS Manager app [41] and Deprexis [91]. In addition, patients with life-changing illnesses (including MS) who use Web-based, quantitative, personal research platforms such as PatientsLikeMe report important benefits such as being able to learn more about their symptoms and understand potential side effects of their treatment [51].

\section{Discussion}

\section{Summary}

There has been a rapid increase in the development, testing, and use of digital and remote communication technologies in MS in recent years, with numerous studies demonstrating the value of these tools. The MS eHealth solutions identified here (Figure 2) mostly support disease monitoring, self-management, treatment, and rehabilitation. A few of these also offer patient advice and education, although apps have also been developed specifically for this. Fewer technologies address screening and remote assessment, and it may be that this area has the greatest scope for the development of new tools in the future.

\section{Principal Findings}

Of the 28 eHealth solutions discussed here, 14 are Web-based (Computerized Specific Training, CSI, Deprexis, HAT, Home eTraining, MAPSS-MS, MCCO, MSDS3D, MS-HAT, MSInvigor8, MSMonitor, MSRS-R, MySupport, and Web Based Physio), and 11 are apps (COGNI-TRAcK, MS Bioscreen, MS Buddy, MSdialog, MS Journal, MSPT, MS self, MyBETAapp, My MS Manager, SymTrac, and TaDiMuS). The remaining three use home-based technologies found in games consoles (ASSESS MS and move II) or specialist equipment (Remote tDCS). Apps are more represented than other platforms among solutions that relate to disease monitoring and self-management, and Web-based solutions account for more of the treatment and rehabilitation solutions than do apps. This trend probably reflects the frequency of use (and hence portability) and data burden (and therefore bandwidth) associated with different solutions.

Although the development of digital and remote communication technologies is welcome, their true value can be realized only if patients and physicians jointly engage with them. Despite the solid evidence base demonstrating the success of telephone-based interventions, many patients with MS do not receive this relatively basic therapy. Thus, it may be helpful to understand what barriers impede delivery of telephone-based rehabilitation before attempts are made to roll out more technologically advanced telehealth solutions on a large scale. It is likely that factors such as mobile Internet access, available bandwidth in remote geographical regions, and cost are all barriers to global uptake of eHealth solutions and that other factors such as availability of specialist clinicians and adaptation of established solutions to suit local situations (language and cultural and educational issues) will need to be overcome. Irrespective of the setting, it is likely that educational programs will be needed as part of training within health care systems to help clinicians understand the value that various communication technologies could bring to routine patient assessment and to ensure that any technologies that are adopted are applied with standardized methods and reporting.

Encouragingly, studies in patients with MS that have examined the use and acceptance of communication technologies suggest that adoption is unlikely to be a major issue; proportionally more patients with MS than in the general population use the Internet in the United States [98], and the majority of German patients at MS specialist centers regularly use modern communication technologies and are happy to use them to communicate with their physicians and other HCPs, including MS nurses [99]. Notably, most patients participating in the North American Research Committee on Multiple Sclerosis Registry (2011) reported that the Internet was their first source for health information [15], and studies examining the browsing habits of patients with MS show that the most-viewed topics related to understanding the disease and treatments [100]. Finally, patients express high levels of satisfaction with home telehealth monitoring [101] and have high levels of acceptance of systems such as MS-HAT [102], finding them easy to use [45].

There are aspects of these technologies with which patients are uncomfortable. Some patients were intimidated by the Nintendo Wii Fit owing to concerns about falling, and some disliked exergaming feedback because it reminded them of their impairments [103]. Furthermore, some were unsure how to use a video game [73], so appropriate training is needed. Particular challenges for those with MS using Web-based technologies include difficulties in reading website text, problems with flashing or moving objects, and operation of a mouse or keyboard because of dexterity issues [96]. Patients can also be unaware of accessibility features that facilitate navigation of websites [96]. Finally, patients may dislike interventions that are overly intrusive, and they may have concerns about security issues associated with remote transmission of personal data. This particular issue may be resolved with emerging security technologies such as Integrated Circuit Metric [104], but these will almost certainly need to be safeguarded with appropriate legislation. 
Figure 2. Overview of electronic health (eHealth) technologies applied in multiple sclerosis. CSI: Cognitive Stability Index; GEMS: Guidelines for Exercise in Multiple Sclerosis; HAT: Home Automated Telemanagement; MCCO: Mellen Center Care Online; MS: multiple sclerosis; MS-HAT: Multiple Sclerosis—-specific version of Home Automated Telemanagement; MSDS3D: Multiple Sclerosis Documentation System: Three-Dimensional; MSPT: Multiple Sclerosis Performance Test; MSRS-R, Multiple Sclerosis Rating Scale-Revised; TaDiMuS: Tablet-based Data capture in Multiple Sclerosis; MAPSS-MS: Memory, Attention and Problem-Solving Skills for Persons with Multiple Sclerosis; ST: specific training; and tDCS: transcranial direct current stimulation.

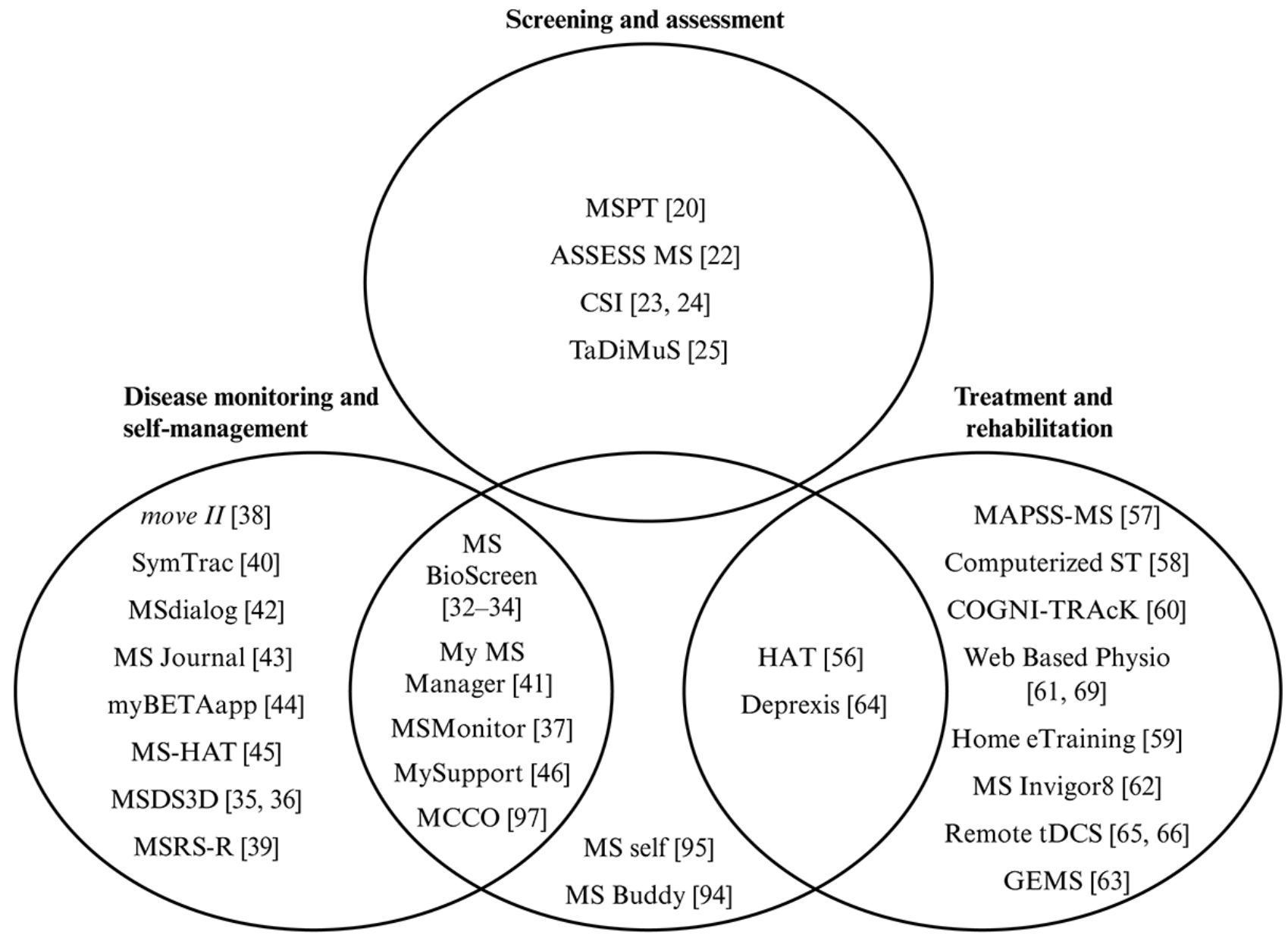

Advice and education

Digital technologies should complement but not replace face-to-face consultations and should thus be welcomed by physicians, especially if they reduce the burden on health care services. It is possible that the high volume of data that certain tools may generate could discourage their adoption clinically, and it is to be determined whether data gathered remotely provide a better picture of disease status than standard follow-up visits and whether these technologies are associated with improvements in long-term patient outcomes. Consensus about which technologies are most useful and cost-effective is lacking, and physicians may be reluctant to invest the time needed to become familiar with such tools, irrespective of any potential efficiency they offer.

In the future, digital and remote technologies may expand to other uses; for example, Web-based platforms such as PatientsLikeMe have been used to develop disease-specific instruments (ie, the MSRS-R) [39], and the Internet-based Dutch Multiple Sclerosis Study used the Internet to recruit patients, monitor symptoms, and capture long-term disease progression data in real-world settings [105]. Similarly, interactive technologies such as the Web-based patient-management system MSDS3D may become increasingly common [106]. There are ongoing initiatives to develop transparent systems for disease monitoring and self-management in MS, such as Remote Assessment of Disease and Relapse in Central Nervous Disorders. This international research project is applying wearable devices and mobile phone technology to develop ways of measuring major depressive disorders, epilepsy, and MS [107]. There is also the MAPPING-MS initiative, a mobile health intervention that will deliver self-management strategies in patients with MS [108]. It seems likely that elements of the many different apps, Web-based tools, and remote monitoring systems that have already been adopted or are in development will become part of larger integrated systems that facilitate eHealth care conveniently for both patients and HCPs.

\section{Conclusions}

In conclusion, many digital and remote communication technology applications have been developed for patients with MS, and evidence is accumulating for the benefits some of these can bring compared with, and complementary to, traditional in-clinic approaches. Most tools focus on disease monitoring, self-management, treatment, and rehabilitation, so greater emphasis could be placed on developing tools dedicated to screening and assessment. However, irrespective of the eHealth 
solution under consideration, data from large, controlled, multicenter trials are lacking (only MSInvigor8 and Deprexis were phase 2 trials), so it is difficult to draw objective conclusions about clinical benefits associated with each technology. Evaluation of eHealth solutions in phase 3 trials may be precluded by cost, in which case prospective surveys in real-world settings [39] or large, retrospective database analyses [46] may be the most pragmatic means of evaluation. Ultimately, the long-term benefits afforded to patients and clinicians by any of these technologies will need to be established before their widespread adoption is likely.

\section{Acknowledgments}

The authors acknowledge Oxford PharmaGenesis for providing editorial and medical writing support, which was funded by Novartis Pharma AG.

\section{Conflicts of Interest}

MM has received lecture fees, travel grants, and fees for consulting from Bayer HealthCare AG, Beiersdorf AG, Biogen Idec GmbH, Merck KGaA, Novartis Pharma GmbH, Pfizer Pharma GmbH, Sanofi-Aventis (Genzyme), and Teva. GB has nothing to disclose. PF has received lecture fees from Excemed and Biogen Idec and consulting fees from Biogen Idec and Novartis. UM-L has received lecture fees and travel grants from Almirall, Bayer, Biogen Idec, Genzyme, Merck Serono, Novartis, Boehringer Ingelheim, Sanofi, and Teva. KV has received lecture fees, travel grants, and fees for consulting from Bayer Schering, Biogen Idec, Genzyme, Merck Serono, Novartis, and Teva. SGM has received honoraria for lecturing and travel expenses for attending meetings and has received financial research support from Bayer, Bayer Schering, Biogen Idec, Genzyme, Merck Serono, MSD, Novartis, Novo Nordisk, Sanofi-Aventis, Teva, and UCB.

\section{References}

1. Khan F, Amatya B, Kesselring J, Galea M. Telerehabilitation for persons with multiple sclerosis. Cochrane Database Syst Rev 2015 Apr 09(4):CD010508. [doi: 10.1002/14651858.CD010508.pub2] [Medline: 25854331]

2. Feys P, Giovannoni G, Dijsselbloem N, Centonze D, Eelen P, Lykke Andersen S. The importance of a multi-disciplinary perspective and patient activation programmes in MS management. Mult Scler 2016 Aug;22(2 Suppl):34-46. [doi: 10.1177/1352458516650741] [Medline: 27465614]

3. Kingwell E, van der Kop M, Zhao Y, Shirani A, Zhu F, Oger J, et al. Relative mortality and survival in multiple sclerosis: findings from British Columbia, Canada. J Neurol Neurosurg Psychiatry 2012 Jan;83(1):61-66. [doi: 10.1136/jnnp-2011-300616] [Medline: 21865212]

4. Khan F, Amatya B, Kesselring J, Galea MP. Telerehabilitation for persons with multiple sclerosis. A Cochrane review. Eur J Phys Rehabil Med 2015 Jun;51(3):311-325 [FREE Full text] [Medline: 25943744]

5. Rasova K, Martinkova P, Pavlikoma M, Cattaneo D, Jonsdottir J, Henze T, et al. Physical therapy provision in multiple sclerosis across Europe: a regional lottery? Eur J Phys Rehabil Med 2015 Dec;51(6):850-852 [FREE Full text] [Medline: 26334364]

6. Berbece C, Gavenas Ž, Kasilingam E. 2013. MS Barometer 2013 URL: http://www.ms-sep.be/userfiles/files/emsp/ MS\%20Barometer\%202013.pdf [accessed 2018-02-23] [WebCite Cache ID 6xRqnNTT9]

7. MSTrust. Is MS care fair? URL: https://www.mstrust.org.uk/file/ms-care-media-reportpdf/download?token=R8dXTbMB [accessed 2017-03-24] [WebCite Cache ID 6pCQSR21t]

8. Eysenbach G. What is e-health? J Med Internet Res 2001 Jun;3(2):E20. [doi: 10.2196/jmir.3.2.e20] [Medline: 11720962]

9. Finlayson M, Holberg C. Evaluation of a teleconference-delivered energy conservation education program for people with multiple sclerosis. Can J Occup Ther 2007 Oct 04;74(4):337-347. [doi: 10.2182/cjot.06.0018] [Medline: 17985756]

10. Balkhi AM, Reid AM, Westen SC, Olsen B, Janicke DM, Geffken GR. Telehealth interventions to reduce management complications in type 1 diabetes: a review. World J Diabetes 2015 Apr 15;6(3):371-379 [FREE Full text] [doi: 10.4239/wjd.v6.i3.371] [Medline: 25897348]

11. Morrison D, Wyke S, Agur K, Cameron EJ, Docking RI, Mackenzie AM, et al. Digital asthma self-management interventions: a systematic review. J Med Internet Res 2014;16(2):e51 [FREE Full text] [doi: 10.2196/jmir.2814] [Medline: 24550161]

12. Godinho C, Domingos J, Cunha G, Santos AT, Fernandes RM, Abreu D, et al. A systematic review of the characteristics and validity of monitoring technologies to assess Parkinson's disease. J Neuroeng Rehabil 2016 Mar 12;13:24 [FREE Full text] [doi: 10.1186/s12984-016-0136-7] [Medline: $\underline{26969628}$ ]

13. Lublin FD, Reingold SC, Cohen JA, Cutter GR, Sørensen PS, Thompson AJ, et al. Defining the clinical course of multiple sclerosis: the 2013 revisions. Neurology 2014 Jul 15;83(3):278-286 [FREE Full text] [doi: 10.1212/WNL.0000000000000560] [Medline: 24871874]

14. WeAreSocial. 2017. Special Reports - Digital in 2017: Global Overview URL: https:/ /wearesocialcom/special-reports/digital-in-2017-global-overview [accessed 2018-02-14] [WebCite Cache ID 6xDzCkVpL]

15. Marrie RA, Salter AR, Tyry T, Fox RJ, Cutter GR. Preferred sources of health information in persons with multiple sclerosis: degree of trust and information sought. J Med Internet Res 2013;15(4):e67 [FREE Full text] [doi: 10.2196/jmir.2466] [Medline: 23635393] 
16. Bosslet GT, Torke AM, Hickman SE, Terry CL, Helft PR. The patient-doctor relationship and online social networks: results of a national survey. J Gen Intern Med 2011 Oct;26(10):1168-1174 [FREE Full text] [doi: 10.1007/s11606-011-1761-2] [Medline: 21706268]

17. Brown J, Ryan C, Harris A. How doctors view and use social media: a national survey. J Med Internet Res 2014;16(12):e267 [FREE Full text] [doi: 10.2196/jmir.3589] [Medline: 25470407]

18. Hatzakis Jr M, Haselkorn J, Williams R, Turner A, Nichol P. Telemedicine and the delivery of health services to veterans with multiple sclerosis. J Rehabil Res Dev 2003;40(3):265-282 [FREE Full text] [Medline: 14582530]

19. Flodgren G, Rachas A, Farmer AJ, Inzitari M, Shepperd S. Interactive telemedicine: effects on professional practice and health care outcomes. Cochrane Database Syst Rev 2015(9):CD002098. [doi: 10.1002/14651858.CD002098.pub2] [Medline: 26343551]

20. Rudick RA, Miller D, Bethoux F, Rao SM, Lee JC, Stough D, et al. The Multiple Sclerosis Performance Test (MSPT): an iPad-based disability assessment tool. J Vis Exp 2014 Jun 30(88):e51318 [FREE Full text] [doi: 10.3791/51318] [Medline: 25046650]

21. Lambercy O, Fluet MC, Lamers I, Kerkhofs L, Feys P, Gassert R. Assessment of upper limb motor function in patients with multiple sclerosis using the Virtual Peg Insertion Test: a pilot study. IEEE Int Conf Rehabil Robot 2013 Jun;2013:6650494. [doi: 10.1109/ICORR.2013.6650494] [Medline: 24187309]

22. Morrison C, D'Souza M, Huckvale K, Dorn JF, Burggraaff J, Kamm CP, et al. Usability and acceptability of ASSESS MS: assessment of motor dysfunction in multiple sclerosis using depth-sensing computer vision. JMIR Hum Factors 2015;2(1):e11 [FREE Full text] [doi: 10.2196/humanfactors.4129] [Medline: 27025782]

23. Younes M, Hill J, Quinless J, Kilduff M, Peng B, Cook SD, et al. Internet-based cognitive testing in multiple sclerosis. Mult Scler 2007 Sep;13(8):1011-1019. [doi: 10.1177/1352458507077626] [Medline: 17623730]

24. Erlanger DM, Kaushik T, Broshek D, Freeman J, Feldman D, Festa J. Development and validation of a web-based screening tool for monitoring cognitive status. J Head Trauma Rehabil 2002 Oct;17(5):458-476. [Medline: 12802255]

25. Beadnall HN, Kuppanda KE, O'Connell A, Hardy TA, Reddel SW, Barnett MH. Tablet-based screening improves continence management in multiple sclerosis. Ann Clin Transl Neurol 2015 Jun;2(6):679-687 [FREE Full text] [doi: 10.1002/acn3.205] [Medline: 26125042]

26. Kurtzke JF. Rating neurologic impairment in multiple sclerosis: an expanded disability status scale (EDSS). Neurology 1983 Nov;33(11):1444-1452. [Medline: 6685237]

27. Leddy S, Hadavi S, McCarren A, Giovannoni G, Dobson R. Validating a novel web-based method to capture disease progression outcomes in multiple sclerosis. J Neurol 2013 Oct;260(10):2505-2510. [doi: 10.1007/s00415-013-7004-1] [Medline: 23807152]

28. Lechner-Scott J, Kappos L, Hofman M, Polman CH, Ronner H, Montalban X, et al. Can the Expanded Disability Status Scale be assessed by telephone? Mult Scler 2003 Mar;9(2):154-159. [doi: 10.1191/1352458503ms884oa] [Medline: 12708811]

29. Nortvedt MW, Riise T, Frugård J, Mohn J, Bakke A, Skår AB, et al. Prevalence of bladder, bowel and sexual problems among multiple sclerosis patients two to five years after diagnosis. Mult Scler 2007 Jan;13(1):106-112. [doi: 10.1177/1352458506071210] [Medline: 17294618]

30. Mahajan ST, Patel PB, Marrie RA. Under treatment of overactive bladder symptoms in patients with multiple sclerosis: an ancillary analysis of the NARCOMS Patient Registry. J Urol 2010 Apr;183(4):1432-1437. [doi: 10.1016/j.juro.2009.12.029] [Medline: 20171697]

31. Ritvo P, Fischer J, Miller D. 1997. Multiple sclerosis quality of life inventory: a user's manual URL: http://walkcoc. nationalmssociety.org/docs/HOM/MSQLI Manual and Forms.pdf [accessed 2018-03-11] [WebCite Cache ID 6xpiDkZwI]

32. University of California San Francisco. The MS Bioscreen URL: http://neurology.ucsf.edu/research/ms-bioscreen [accessed 2017-03-22] [WebCite Cache ID 6p9WCDAnt]

33. Gourraud PA, Henry RG, Cree BA, Crane JC, Lizee A, Olson MP, et al. Precision medicine in chronic disease management: the multiple sclerosis BioScreen. Ann Neurol 2014 Nov;76(5):633-642 [FREE Full text] [doi: 10.1002/ana.24282] [Medline: 25263997]

34. Hauser S, Gourraud PA. 2013. MS Bioscreen Project Summary URL: http://campuslifeservices.ucsf.edu/upload/neurology/ files/Bioscreen_Research_Summary.pdf[WebCite Cache ID 6p9b7T6KV]

35. Kern R, Haase R, Eisele JC, Thomas K, Ziemssen T. Designing an electronic patient management system for multiple sclerosis: building a next generation multiple sclerosis documentation system. Interact J Med Res 2016 Jan 08;5(1):e2 [FREE Full text] [doi: 10.2196/ijmr.4549] [Medline: 26746977]

36. Eisele J, Kern R, Alexander S, Großmann L, Schultheiss T, Ziemssen T. Multiple Sclerosis Documentation System MSDS3D - innovative management of patients with multiple sclerosis (I8-1.003). Neurology 2014 Apr;82(10 supplement) [FREE Full text]

37. Jongen PJ, Sinnige LG, van Geel BM, Verheul F, Verhagen WI, van der Kruijk RA, et al. The interactive web-based program MSmonitor for self-management and multidisciplinary care in multiple sclerosis: utilization and valuation by patients. Patient Prefer Adherence 2016;10:243-250 [FREE Full text] [doi: 10.2147/PPA.S93786] [Medline: 27042018] 
38. Shammas L, Zentek T, von Haaren B, Schlesinger S, Hey S, Rashid A. Home-based system for physical activity monitoring in patients with multiple sclerosis (Pilot study). Biomed Eng Online 2014 Feb 06;13:10 [FREE Full text] [doi: 10.1186/1475-925X-13-10] [Medline: 24502230]

39. Wicks P, Vaughan TE, Massagli MP. The multiple sclerosis rating scale, revised (MSRS-R): development, refinement, and psychometric validation using an online community. Health Qual Life Outcomes 2012 Jun 18;10:70 [FREE Full text] [doi: 10.1186/1477-7525-10-70] [Medline: 22709981]

40. Novartis. SymTrac URL: https://www.novartis.co.uk/symtrac.shtml [accessed 2018-02-14] [WebCite Cache ID 6xE05SooG]

41. Multiple Sclerosis Association of America. Mymsaa. My MS Manager ${ }^{\mathrm{TM}}$ URL: https://mymsaa.org/msaa-community/ mobile/ [accessed 2018-02-14] [WebCite Cache ID 6xE0ESd7z]

42. Greiner P, Sawka A, Imison E. Patient and physician perspectives on MSdialog, an electronic PRO diary in multiple sclerosis. Patient 2015 Dec;8(6):541-550 [FREE Full text] [doi: 10.1007/s40271-015-0140-1] [Medline: 26350792]

43. Tensai Solutions LLC. MS Journal URL: $\underline{\text { https://itunes.apple.com/us/app/ms-journal/id523663325[WebCite Cache ID }}$ 6xE0TsSZr]

44. Betaseron. myBETAapp ${ }^{\mathrm{TM}}$ URL: https://www.betaseron.com/betaconnect-system/mybetaapp/ [accessed 2018-02-14] [WebCite Cache ID 6xE0n2vG1]

45. Settle JR, Maloni HW, Bedra M, Finkelstein J, Zhan M, Wallin MT. Monitoring medication adherence in multiple sclerosis using a novel web-based tool: A pilot study. J Telemed Telecare 2016 Jun;22(4):225-233. [doi: 10.1177/1357633X15597115] [Medline: 26253748]

46. Roche J, McCarry Y, Mellors K. Enhanced patient support services improve patient persistence with multiple sclerosis treatment. Patient Prefer Adherence 2014;8:805-811 [FREE Full text] [doi: 10.2147/PPA.S59496] [Medline: 24966668]

47. Jongen PJ, Sinnige LG, van Geel BM, Verheul F, Verhagen WI, van der Kruijk RA, et al. The interactive web-based program MSmonitor for self-management and multidisciplinary care in multiple sclerosis: concept, content, and pilot results. Patient Prefer Adherence 2015;9:1741-1750 [FREE Full text] [doi: 10.2147/PPA.S93783] [Medline: 26715841]

48. Gijbels D, Alders G, Van Hoof E, Charlier C, Roelants M, Broekmans T, et al. Predicting habitual walking performance in multiple sclerosis: relevance of capacity and self-report measures. Mult Scler 2010 May;16(5):618-626. [doi: 10.1177/1352458510361357] [Medline: 20207785]

49. Viqueira Villarejo M, Maeso Garcia J, García Zapirain B, Méndez Zorrilla A. Technological solution for determining gait parameters using pressure sensors: a case study of multiple sclerosis patients. Biomed Mater Eng 2014;24(6):3511-3522. [doi: 10.3233/BME-141177] [Medline: 25227064]

50. Sola-Valls N, Blanco Y, Sepúlveda M, Llufriu S, Martínez-Lapiscina EH, La PD, et al. Walking function in clinical monitoring of multiple sclerosis by telemedicine. J Neurol 2015 Jul;262(7):1706-1713. [doi: 10.1007/s00415-015-7764-x] [Medline: 25957639]

51. Wicks P, Massagli M, Frost J, Brownstein C, Okun S, Vaughan T, et al. Sharing health data for better outcomes on PatientsLikeMe. J Med Internet Res 2010;12(2):e19 [FREE Full text] [doi: 10.2196/jmir.1549] [Medline: 20542858]

52. Roberts M, Lush T, Pohorely J. Improving reporting of multiple sclerosis relapse. Nurs Times 2015;111(48):12-14. [Medline: 26775329]

53. Rebismart. What is MSdialog? URL: http://www.rebismart.com/en/msdialog/what_is_msdialog/what_is_msdialog.html [accessed 2018-02-14] [WebCite Cache ID 6xE0JAuan]

54. Rebismart. What is RebiSmart®? URL: http://www.rebismart.com/en/rebismart/what is rebismart/what is rebismart.html [accessed 2018-02-14] [WebCite Cache ID 6xE0MZZ39]

55. Heesen C, Bruce J, Feys P, Sastre-Garriga J, Solari A, Eliasson L, et al. Adherence in multiple sclerosis (ADAMS): classification, relevance, and research needs. A meeting report. Mult Scler 2014 Nov;20(13):1795-1798. [doi: 10.1177/1352458514531348] [Medline: 24756569]

56. Finkelstein J, Wood J. Design and implementation of Home Automated Telemanagement system for patients with multiple sclerosis. Conf Proc IEEE Eng Med Biol Soc 2009;2009:6091-6094. [doi: 10.1109/IEMBS.2009.5334948] [Medline: 19965257]

57. Stuifbergen AK, Becker H, Perez F, Morison J, Kullberg V, Todd A. A randomized controlled trial of a cognitive rehabilitation intervention for persons with multiple sclerosis. Clin Rehabil 2012 Oct;26(10):882-893. [doi: 10.1177/0269215511434997] [Medline: 22301679]

58. Amato MP, Goretti B, Viterbo RG, Portaccio E, Niccolai C, Hakiki B, et al. Computer-assisted rehabilitation of attention in patients with multiple sclerosis: results of a randomized, double-blind trial. Mult Scler 2014 Jan;20(1):91-98. [doi: 10.1177/1352458513501571] [Medline: 23959713]

59. Frevel D, Mäurer M. Internet-based home training is capable to improve balance in multiple sclerosis: a randomized controlled trial. Eur J Phys Rehabil Med 2015 Feb;51(1):23-30 [FREE Full text] [Medline: 24755773]

60. Tacchino A, Pedullà L, Bonzano L, Vassallo C, Battaglia MA, Mancardi G, et al. A new app for at-home cognitive training: description and pilot testing on patients with multiple sclerosis. JMIR Mhealth Uhealth 2015 Aug 31;3(3):e85 [FREE Full text] [doi: 10.2196/mhealth.4269] [Medline: 26323749] 
61. Paul L, Coulter EH, Miller L, McFadyen A, Dorfman J, Mattison PG. Web-based physiotherapy for people moderately affected with multiple sclerosis; quantitative and qualitative data from a randomized, controlled pilot study. Clin Rehabil 2014 Sep;28(9):924-935. [doi: 10.1177/0269215514527995] [Medline: 24691218]

62. Moss-Morris R, McCrone P, Yardley L, van Kessel K, Wills G, Dennison L. A pilot randomised controlled trial of an Internet-based cognitive behavioural therapy self-management programme (MS Invigor8) for multiple sclerosis fatigue. Behav Res Ther 2012 Jun;50(6):415-421. [doi: 10.1016/j.brat.2012.03.001] [Medline: 22516321]

63. Adamson BC, Learmonth YC, Kinnett-Hopkins D, Bohri M, Motl RW. Feasibility study design and methods for Project GEMS: Guidelines for Exercise in Multiple Sclerosis. Contemp Clin Trials 2016 Mar;47:32-39. [doi: 10.1016/j.cct.2015.12.002] [Medline: 26655434]

64. Fischer A, Schröder J, Vettorazzi E, Wolf OT, Pöttgen J, Lau S, et al. An online programme to reduce depression in patients with multiple sclerosis: a randomised controlled trial. Lancet Psychiatry 2015 Mar;2(3):217-223. [doi:

10.1016/S2215-0366(14)00049-2] [Medline: 26359900]

65. Kasschau M, Reisner J, Sherman K, Bikson M, Datta A, Charvet LE. Transcranial direct current stimulation is feasible for remotely supervised home delivery in multiple sclerosis. Neuromodulation 2016 Dec;19(8):824-831. [doi: 10.1111/ner.12430] [Medline: 27089545]

66. Kasschau M, Sherman K, Haider L, Frontario A, Shaw M, Datta A, et al. A protocol for the use of remotely-supervised transcranial direct current stimulation (tDCS) in multiple sclerosis (MS). J Vis Exp 2015 Dec 26(106):e53542 [FREE Full text] [doi: 10.3791/53542] [Medline: 26780383]

67. Stuifbergen A, Becker H, Morgan S, Morrison J, Perez F. Home-based computer-assisted cognitive training: feasibility and perceptions of people with multiple sclerosis. Int J MS Care 2011 Jan 01;13(4):189-198 [FREE Full text] [doi: 10.7224/1537-2073-13.4.189] [Medline: 22740777]

68. Pedullà L, Brichetto G, Tacchino A, Vassallo C, Zaratin P, Battaglia MA, et al. Adaptive vs. non-adaptive cognitive training by means of a personalized app: a randomized trial in people with multiple sclerosis. J Neuroeng Rehabil 2016 Oct 04;13(1):88 [FREE Full text] [doi: 10.1186/s12984-016-0193-y] [Medline: 27716336]

69. Paul L. Web based physiotherapy URL: https://www.webbasedphysio.com/ [accessed 2018-02-14] [WebCite Cache ID $\underline{6 x E 15 \mathrm{rozW}]}$

70. Finkelstein J, Lapshin O, Castro H, Cha E, Provance PG. Home-based physical telerehabilitation in patients with multiple sclerosis: a pilot study. J Rehabil Res Dev 2008;45(9):1361-1373 [FREE Full text] [Medline: 19319760]

71. Motl RW, Dlugonski D. Increasing physical activity in multiple sclerosis using a behavioral intervention. Behav Med 2011 Oct;37(4):125-131. [doi: 10.1080/08964289.2011.636769] [Medline: 22168329]

72. Dlugonski D, Motl RW, Mohr DC, Sandroff BM. Internet-delivered behavioral intervention to increase physical activity in persons with multiple sclerosis: sustainability and secondary outcomes. Psychol Health Med 2012;17(6):636-651. [doi: 10.1080/13548506.2011.652640] [Medline: 22313192]

73. Forsberg A, Nilsagård Y, Boström K. Perceptions of using videogames in rehabilitation: a dual perspective of people with multiple sclerosis and physiotherapists. Disabil Rehabil 2015;37(4):338-344 [FREE Full text] [doi: 10.3109/09638288.2014.918196] [Medline: 24833535]

74. Pau M, Coghe G, Corona F, Leban B, Marrosu MG, Cocco E. Effectiveness and limitations of unsupervised home-based balance rehabilitation with Nintendo Wii in people with multiple sclerosis. Biomed Res Int 2015;2015:916478 [FREE Full text] [doi: 10.1155/2015/916478] [Medline: 26583146]

75. Taylor MJ, Griffin M. The use of gaming technology for rehabilitation in people with multiple sclerosis. Mult Scler 2015 Apr;21(4):355-371. [doi: 10.1177/1352458514563593] [Medline: 25533296]

76. Brichetto G, Spallarossa P, de Carvalho ML, Battaglia MA. The effect of Nintendo® Wii ${ }^{\circledR}$ on balance in people with multiple sclerosis: a pilot randomized control study. Mult Scler 2013 Aug;19(9):1219-1221. [doi: 10.1177/1352458512472747] [Medline: 23322502]

77. Nilsagård YE, Forsberg AS, von Koch L. Balance exercise for persons with multiple sclerosis using Wii games: a randomised, controlled multi-centre study. Mult Scler 2013 Feb;19(2):209-216. [doi: 10.1177/1352458512450088] [Medline: 22674972]

78. Robinson J, Dixon J, Macsween A, van Schaik P, Martin D. The effects of exergaming on balance, gait, technology acceptance and flow experience in people with multiple sclerosis: a randomized controlled trial. BMC Sports Sci Med Rehabil 2015;7:8 [FREE Full text] [doi: 10.1186/s13102-015-0001-1] [Medline: 25969739]

79. Prosperini L, Fanelli F, Petsas N, Sbardella E, Tona F, Raz E, et al. Multiple sclerosis: changes in microarchitecture of white matter tracts after training with a video game balance board. Radiology 2014 Nov;273(2):529-538. [doi: 10.1148/radiol.14140168] [Medline: 25158046]

80. Eguiluz-Perez G, Garcia-Zapirain B. Comprehensive verticality analysis and web-based rehabilitation system for people with multiple sclerosis with supervised medical monitoring. Biomed Mater Eng 2014;24(6):3493-3502. [doi: 10.3233/BME-141175] [Medline: 25227062]

81. Ehde DM, Elzea JL, Verrall AM, Gibbons LE, Smith AE, Amtmann D. Efficacy of a telephone-delivered self-management intervention for persons with multiple sclerosis: a randomized controlled trial with a one-year follow-up. Arch Phys Med Rehabil 2015 Nov;96(11):1945-58.e2. [doi: 10.1016/j.apmr.2015.07.015] [Medline: 26254948] 
82. Baron KG, Corden M, Jin L, Mohr DC. Impact of psychotherapy on insomnia symptoms in patients with depression and multiple sclerosis. J Behav Med 2011 Apr;34(2):92-101 [FREE Full text] [doi: 10.1007/s10865-010-9288-2] [Medline: 20809354]

83. Turner AP, Hartoonian N, Sloan AP, Benich M, Kivlahan DR, Hughes C, et al. Improving fatigue and depression in individuals with multiple sclerosis using telephone-administered physical activity counseling. J Consult Clin Psychol 2016 Apr;84(4):297-309. [doi: 10.1037/ccp0000086] [Medline: 26913621]

84. Mohr DC, Likosky W, Bertagnolli A, Goodkin DE, Van Der Wende J, Dwyer P, et al. Telephone-administered cognitive-behavioral therapy for the treatment of depressive symptoms in multiple sclerosis. J Consult Clin Psychol 2000 Apr;68(2):356-361. [Medline: 10780138$]$

85. Cosio D, Jin L, Siddique J, Mohr DC. The effect of telephone-administered cognitive-behavioral therapy on quality of life among patients with multiple sclerosis. Ann Behav Med 2011 Apr;41(2):227-234 [FREE Full text] [doi:

10.1007/s12160-010-9236-y] [Medline: 21069585]

86. Pilutti LA, Dlugonski D, Sandroff BM, Klaren R, Motl RW. Randomized controlled trial of a behavioral intervention targeting symptoms and physical activity in multiple sclerosis. Mult Scler 2014 Apr;20(5):594-601. [doi: 10.1177/1352458513503391] [Medline: 24009162]

87. Boeschoten RE, Dekker J, Uitdehaag BM, Polman CH, Collette EH, Cuijpers P, et al. Internet-based self-help treatment for depression in multiple sclerosis: study protocol of a randomized controlled trial. BMC Psychiatry 2012 Sep 11;12:137 [FREE Full text] [doi: 10.1186/1471-244X-12-137] [Medline: 22967202]

88. Cavalera C, Pagnini F, Rovaris M, Mendozzi L, Pugnetti L, Garegnani M, et al. A telemedicine meditation intervention for people with multiple sclerosis and their caregivers: study protocol for a randomized controlled trial. Trials 2016 Jan 04;17:4 [FREE Full text] [doi: 10.1186/s13063-015-1136-9] [Medline: 26729330]

89. Egner A, Phillips VL, Vora R, Wiggers E. Depression, fatigue, and health-related quality of life among people with advanced multiple sclerosis: results from an exploratory telerehabilitation study. NeuroRehabilitation 2003;18(2):125-133. [Medline: $\underline{12867675]}$

90. van Kessel K, Wouldes T, Moss-Morris R. A New Zealand pilot randomized controlled trial of a web-based interactive self-management programme (MSInvigor8) with and without email support for the treatment of multiple sclerosis fatigue. Clin Rehabil 2016 May;30(5):454-462. [doi: 10.1177/0269215515584800] [Medline: 25952587]

91. Deprexis. Deprexis: the effective online program for treating depression URL: http://deprexis.com/ [accessed 2017-03-22] [WebCite Cache ID 6p9bmbu1T]

92. Tallner A, Streber R, Hentschke C, Morgott M, Geidl W, Mäurer M, et al. Internet-supported physical exercise training for persons with multiple sclerosis-a randomised, controlled study. Int J Mol Sci 2016 Sep 30;17(10) [FREE Full text] [doi: 10.3390/ijms17101667] [Medline: 27706046]

93. Tallner A, Pfeifer K, Mäurer M. Web-based interventions in multiple sclerosis: the potential of tele-rehabilitation. Ther Adv Neurol Disord 2016 Jul;9(4):327-335 [FREE Full text] [doi: 10.1177/1756285616640684] [Medline: 27366240]

94. Healthline Networks Inc. MS Buddy (version 2.0.1) URL: https://itunes.apple.com/us/app/ms-buddy/id1040195462[WebCite Cache ID 6xE7hG7b0]

95. Acorda Therapeutics Inc. MS self ${ }^{\mathrm{TM}}$, the Multiple Sclerosis Mobile App URL: http://www.moveoverms.org/ multiple-sclerosis-app-ms-self/ [accessed 2018-02-14] [WebCite Cache ID 6xE9pDCXJ]

96. Atreja A, Mehta N, Miller D, Moore S, Nichols K, Miller H, et al. One size does not fit all: using qualitative methods to inform the development of an Internet portal for multiple sclerosis patients. AMIA Annu Symp Proc 2005 Jan 1:16-20 [FREE Full text] [Medline: 16778993]

97. Miller DM, Moore SM, Fox RJ, Atreja A, Fu AZ, Lee J, et al. Web-based self-management for patients with multiple sclerosis: a practical, randomized trial. Telemed J E Health 2011;17(1):5-13 [FREE Full text] [doi: 10.1089/tmj.2010.0133] [Medline: 21214498]

98. Nielsen AS, Halamka JD, Kinkel RP. Internet portal use in an academic multiple sclerosis center. J Am Med Inform Assoc 2012 Feb;19(1):128-133 [FREE Full text] [doi: 10.1136/amiajnl-2011-000177] [Medline: 21571744]

99. Haase R, Schultheiss T, Kempcke R, Thomas K, Ziemssen T. Use and acceptance of electronic communication by patients with multiple sclerosis: a multicenter questionnaire study. J Med Internet Res 2012;14(5):e135 [FREE Full text] [doi: 10.2196/jmir.2133] [Medline: 23069209]

100. Lejbkowicz I, Paperna T, Stein N, Dishon S, Miller A. Internet usage by patients with multiple sclerosis: implications to participatory medicine and personalized healthcare. Mult Scler Int 2010;2010:640749 [FREE Full text] [doi: 10.1155/2010/640749] [Medline: 22096625]

101. Turner AP, Wallin MT, Sloan A, Maloni H, Kane R, Martz L, et al. Clinical management of multiple sclerosis through home telehealth monitoring: results of a pilot project. Int J MS Care 2013;15(1):8-14 [FREE Full text] [doi: 10.7224/1537-2073.2012-012] [Medline: 24453757]

102. Cha E, Castro HK, Provance P, Finkelstein J. Acceptance of home telemanagement is high in patients with multiple sclerosis. AMIA Annu Symp Proc 2007 Oct 11:893. [Medline: 18693994]

103. Plow M, Finlayson M. A qualitative study exploring the usability of Nintendo Wii Fit among persons with multiple sclerosis. Occup Ther Int 2014 Mar;21(1):21-32. [doi: 10.1002/oti.1345] [Medline: 23613154] 
104. Tahir R, Tahir H, McDonald-Maier K. Securing health sensing using integrated circuit metric. Sensors (Basel) 2015 Oct 20;15(10):26621-26642 [FREE Full text] [doi: 10.3390/s151026621] [Medline: 26492250]

105. Jongen PJ, Heerings M, Lemmens WA, Donders R, van der Zande A, van Noort E, et al. A prospective web-based patient-centred interactive study of long-term disabilities, disabilities perception and health-related quality of life in patients with multiple sclerosis in The Netherlands: the Dutch Multiple Sclerosis Study protocol. BMC Neurol 2015 Aug 04;15:128 [FREE Full text] [doi: 10.1186/s12883-015-0379-0] [Medline: 26238866]

106. Ziemssen T, Kempcke R, Eulitz M, Großmann L, Suhrbier A, Thomas K, et al. Multiple sclerosis documentation system (MSDS): moving from documentation to management of MS patients. J Neural Transm 2013 Sep;120 Suppl 1:S61-S66. [doi: 10.1007/s00702-013-1041-x] [Medline: 23728704]

107. Hotopf M, Narayan V. Radar-cns. 2016. Remote Assessment of Disease and Relapse in Central Nervous System Disorders (RADAR-CNS) URL: https://www.radar-cns.org/ [accessed 2018-02-14] [WebCite Cache ID 6xE9If2CV]

108. Brichetto G, De Vita I, Tacchino A, Bulgheroni M, d'Amico E. Assessment of an m-health intervention to deliver self-management strategies in patients with multiple sclerosis. 2016 Presented at: Lancet Neurology conference; October, 19-21; London, UK.

\author{
Abbreviations \\ ADL: activities of daily living \\ BDI: Beck Depression Inventory \\ BLCS: Bladder Control Scale \\ BWCS: Bowel Control Scale \\ CBT: cognitive behavioral therapy \\ CSI: Cognitive Stability Index \\ EDSS: Expanded Disability Status Scale \\ eHealth: electronic health \\ GEMS: Guidelines for Exercise in Multiple Sclerosis \\ HAT: Home Automated Telemanagement \\ HCP: health care professional \\ MACFIMS: Minimal Assessment of Cognitive Function in Multiple Sclerosis \\ MAPSS-MS: Memory, Attention and Problem-Solving Skills for Persons with Multiple Sclerosis \\ MCCO: Mellen Center Care Online \\ MS: multiple sclerosis \\ MSDS3D: Multiple Sclerosis Documentation System: Three-Dimensional \\ MS-HAT: Multiple Sclerosis—specific version of Home Automated Telemanagement \\ MSPT: Multiple Sclerosis Performance Test \\ MSRS-R: Multiple Sclerosis Rating Scale-Revised \\ PA: physical activity \\ PASAT: Paced Auditory Serial Addition Test \\ QoL: quality of life \\ RC: routine care \\ RRMS: relapsing-remitting multiple sclerosis \\ TaDiMuS: Tablet-based Data capture in Multiple Sclerosis \\ tDCS: transcranial direct current stimulation \\ 3D: three-dimensional
}

Edited by G Eysenbach; submitted 05.04.17; peer-reviewed by R Haase, J Apolinário-Hagen; comments to author 22.07.17; revised
version received 08.01.18; accepted 26.01.18; published 24.04.18
Please cite as:
Marziniak M, Brichetto G, Feys P, Meyding-Lamadé U, Vernon K, Meuth SG
The Use of Digital and Remote Communication Technologies as a Tool for Multiple Sclerosis Management: Narrative Review
JMIR Rehabil Assist Technol 2018;5(1):e5
URL: $\underline{\text { http://rehab.jmir.org/2018/1/e5/ }}$
doi: $\underline{10.2196 / \text { rehab.7805 }}$
PMID: $\underline{29691208}$


(CMartin Marziniak, Giampaolo Brichetto, Peter Feys, Uta Meyding-Lamadé, Karen Vernon, Sven G. Meuth. Originally published in JMIR Rehabilitation and Assistive Technology (http://rehab.jmir.org), 24.04.2018. This is an open-access article distributed under the terms of the Creative Commons Attribution License (https://creativecommons.org/licenses/by/4.0/), which permits unrestricted use, distribution, and reproduction in any medium, provided the original work, first published in JMIR Rehabilitation and Assistive Technology, is properly cited. The complete bibliographic information, a link to the original publication on http://rehab.jmir.org/, as well as this copyright and license information must be included. 